\title{
Groundwater-driven nutrient inputs to coastal lagoons: the relevance of lagoon water recirculation as a conveyor of dissolved nutrients
}

Valentí Rodellas ${ }^{1 *}$, Thomas C. Stieglitz ${ }^{1,2}$, Aladin Andrisoa ${ }^{1}$, Peter G. Cook ${ }^{3,4}$, Patrick

Raimbault ${ }^{5}$, Joseph J. Tamborski ${ }^{6}$, Pieter van Beek ${ }^{6}$, Olivier Radakovitch ${ }^{1,7}$

${ }^{1}$ Aix-Marseille Univ, CNRS, IRD, INRA, Coll France, CEREGE, 13545 Aix-en-Provence, France

${ }^{2}$ Centre for Tropical Water and Aquatic Ecosystem Research, James Cook University, Townsville, Queensland 4811, Australia

${ }^{3}$ National Centre for Groundwater Research and Training (NCGRT), School of the Environment, Flinders University, Adelaide SA 5001, Australia

${ }^{4}$ Aix-Marseille Université, IMéRA, 13000 Marseille, France

${ }^{5}$ Aix Marseille Université, CNRS/INSU, Université de Toulon, IRD, Mediterranean Institute of Oceanography (MIO), UM110, 13288 Marseille, France

${ }^{6}$ LEGOS (CNRS/UPS/CNES/IRD), Observatoire Midi Pyrénées, 14 Ave Edouard Belin, 31400 Toulouse, France

${ }^{7}$ Institut de Radioprotection et de Sureté Nucléaire (IRSN), PSE-ENV/SRTE/LRTA, BP 3, 13115 Saint-Paul-Les-Durance, France

*Corresponding Author: Valentí Rodellas (rodellas@cerege.fr) 


\section{Abstract}

Evaluating the sources of nutrient inputs to coastal lagoons is required to understand the functioning of these ecosystems and their vulnerability to eutrophication. Whereas terrestrial groundwater processes are increasingly recognized as relevant sources of nutrients to coastal lagoons, there are still limited studies evaluating separately nutrient fluxes driven by terrestrial groundwater discharge and lagoon water recirculation through sediments. In this study, we assess the relative significance of these sources in conveying dissolved inorganic nutrients $\left(\mathrm{NO}_{3}{ }^{-}, \mathrm{NH}_{4}{ }^{+}\right.$and $\left.\mathrm{PO}_{4}{ }^{3-}\right)$ to a coastal lagoon (La Palme lagoon; France, Mediterranean Sea) using concurrent water and radon mass balances. The recirculation of lagoon water through sediments represents a source of $\mathrm{NH}_{4}^{+}$ $\left(1900-5500 \mathrm{~mol} \mathrm{~d}^{-1}\right)$ and $\mathrm{PO}_{4}^{3-}\left(22-71 \mathrm{~mol} \mathrm{~d}^{-1}\right)$, but acts as a sink of $\mathrm{NO}_{3}{ }^{-}$. Estimated karstic groundwater-driven inputs of $\mathrm{NO}_{3}{ }^{-}, \mathrm{NH}_{4}{ }^{+}$and $\mathrm{PO}_{4}{ }^{3-}$ to the lagoon are on the order of $200-1200,1-12$ and $1.5-8.7 \mathrm{~mol} \mathrm{~d}^{-1}$, respectively. A comparison between the main nutrient sources to the lagoon (karstic groundwater, recirculation, diffusion from sediments, inputs from a sewage treatment plant and atmospheric deposition) reveals that the recirculation of lagoon water through sediments is the main source of both dissolved inorganic nitrogen (DIN) and phosphorous (DIP) to La Palme lagoon. These results are in contrast with several studies conducted in systems influenced by terrestrial groundwater inputs, where groundwater is often assumed to be the main pathway for dissolved inorganic nutrient loads. This work highlights the important role of lagoon water recirculation through permeable sediments as a major conveyor of dissolved nutrients to coastal lagoons and, thus, the need for a sound 
understanding of the recirculation-driven nutrient fluxes and their ecological implications to sustainably manage lagoonal ecosystems.

Keywords: recirculation, groundwater, radon, nutrients, coastal lagoons, eutrophication

\section{Graphical Abstract}

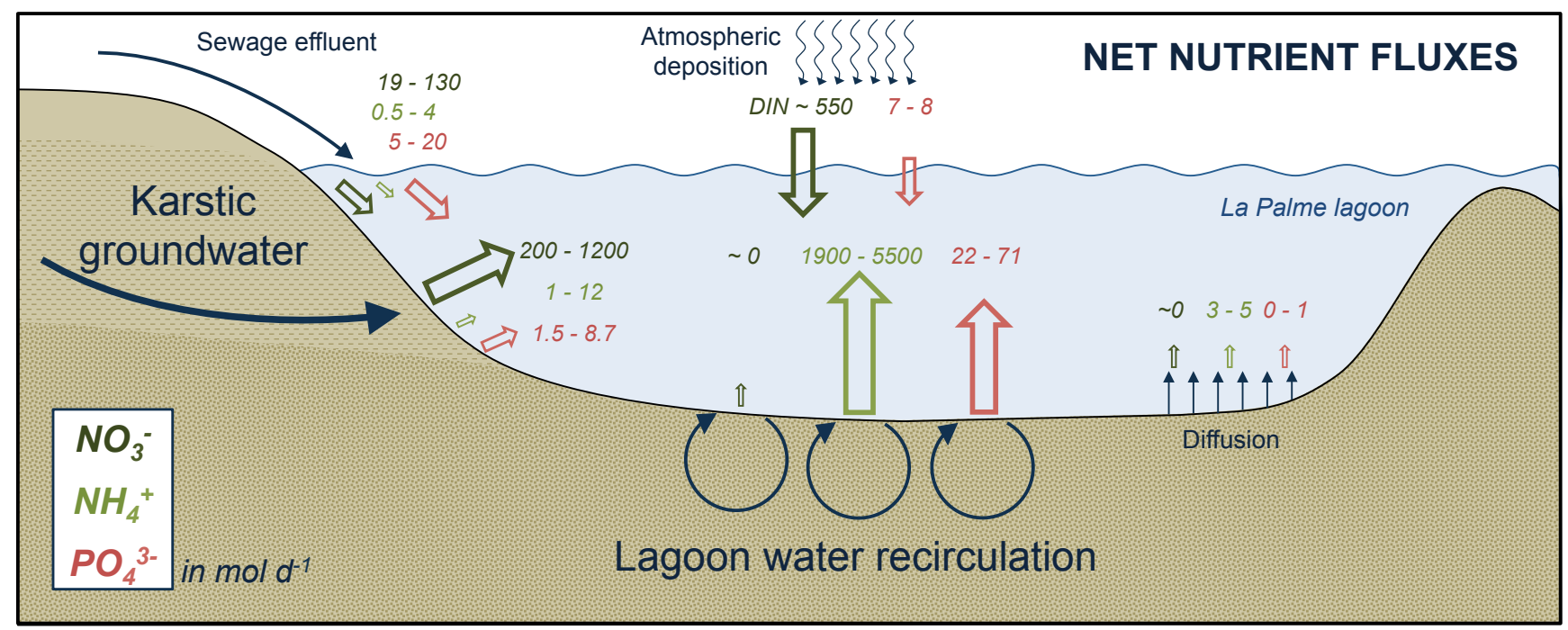




\section{INTRODUCTION}

Coastal lagoons host some of the most dynamic, diverse and productive ecosystems on Earth, and provide a wide range of goods and services of a great socio-economic value to coastal communities (Beer and Joyce, 2013; Kjerfve, 1994; Newton et al., 2014). These ecosystems are threatened by anthropogenic and climatic disturbances that lead to land reclamation, loss of habitats and vegetation and significant pressure on biological and ecological resources (de Jonge et al., 2002; Jennerjahn and Mitchell, 2013). These semi-enclosed coastal ecosystems are characterized by a restricted water exchange with the ocean that favors the accumulation of chemical compounds, and they are thus strongly dependent on watershed inputs. This results in systems extremely vulnerable to eutrophication, mainly driven by increasing nutrient inputs from untreated domestic or industrial sewage and/or the use of fertilizers for agriculture in the surrounding watershed (Brito et al., 2012; Cloern, 2001; Howarth et al., 2011; Lloret et al., 2008). Eutrophication of coastal surface waters may lead to recurrent toxic algal blooms, hypoxia, changes in aquatic species community structure and losses of biodiversity (Garcés et al., 2011; Gobler and Sañudo-Wilhelmy, 2001; Lee and Kim, 2007; Valiela et al., 1992). Understanding the origin and pathways of nutrient inputs to coastal lagoons is thus as an essential step towards the mitigation of the negative effects of eutrophication in these coastal ecosystems.

While the role of surface water discharge as a source of dissolved nutrients to coastal ecosystems has been well documented for decades, groundwater processes have only recently been recognized as important contributors to their hydrological and biogeochemical budgets (Moore, 2010; Slomp and Van Cappellen, 2004; 
Windom et al., 2006). Several studies provide increasing evidence for groundwater as an important source of nutrients to coastal wetlands and lagoons, bays and coves, salt marshes, coral reefs or entire ocean basins, sometimes rivaling loads from riverine inputs (e.g. Adyasari et al., 2018; Beusen et al., 2013; Rodellas et al., 2015; Sadat-Noori et al., 2016; Slomp and Van Cappellen, 2004; Szymczycha et al., 2012). These evaluations usually incorporate nutrient inputs associated with the discharge of fresh terrestrial groundwater from coastal aquifers, but also to the recirculation of seawater (or lagoon water) through permeable sediments. These two disparate processes are commonly incorporated within the definition of Submarine Groundwater Discharge (SGD), mainly because both processes represent advective water flows across the sediment-water interface that can supply chemical loads to coastal and lagoonal waters (Burnett et al., 2006; Moore, 2010). Terrestrial groundwater discharge is a source of new nutrients to coastal systems, derived from natural (e.g. vegetation, rocks, microorganisms) and anthropogenic (e.g. agriculture, industrial and domestic wastewaters) sources to coastal aquifers (Knee and Paytan, 2011; Slomp and Van Cappellen, 2004). Whilst seawater recirculation does not represent a net input of water, it can also result in a significant net flux of nutrients to coastal waters mainly as a consequence of i) the biogeochemical transformations occurring when fresh groundwater mixes with seawater in coastal aquifers and permeable coastal sediments (Moore, 1999; Santos et al., 2008); ii) the continuous supply of oxidants and fine particulate and dissolved matter into sediment porewaters that fuel biological and chemical reactions within sediments (Anschutz et al., 2009; Huettel et al., 2014); and iii) the remobilization of nutrients stored in sediments as a consequence of past regimes or anthropogenic activities (Martínez-Soto et al., 2016; Trezzi et al., 2016). 
Therefore, the biogeochemical composition of terrestrial groundwater discharge and saline recirculation flows may be considerably different, requiring the separation of both processes to better understand and characterize fluxes of dissolved nutrients to coastal lagoons and their ecological implications (SadatNoori et al., 2016; Weinstein et al., 2011). However, there are still limited studies that have attempted to distinguish nutrient fluxes driven by terrestrial groundwater and recirculation inputs (e.g. Kroeger and Charette, 2008a; SadatNoori et al., 2016; Santos et al., 2009; Tamborski et al., 2017; Weinstein et al., 2011), and these are rarely focused on lagoonal ecosystems. Most studies conducted in coastal lagoons are based on nutrient fluxes supplied by terrestrial groundwater (e.g. Ji et al., 2013; Malta et al., 2017; Tait et al., 2014) and neglect the potential role of water recirculation through sediments as a pathway for dissolved nutrients loads.

In this study, we assess the relative significance of terrestrial groundwater discharge from a karst origin (referred hereinafter as karstic groundwater) and saline water recirculation through sediments in conveying dissolved nutrients to a coastal lagoon. This study was conducted in La Palme lagoon (France, Mediterranean Sea), a small shallow coastal lagoon where both the discharge of karstic groundwater and the recirculation of lagoon water through permeable sediments have been documented previously (Bejannin et al., 2017; Stieglitz et al., 2013a). In this paper, detailed estimations of fluxes of dissolved inorganic nutrients $\left(\mathrm{NO}_{3}{ }^{-}, \mathrm{NH}_{4}{ }^{+}\right.$and $\left.\mathrm{PO}_{4}{ }^{3-}\right)$ driven by karstic groundwater discharge and lagoon water recirculation are conducted via concurrent water and radon mass balances. 
Terminology: Advective fluxes occurring over small spatial scales ( $\mathrm{mm}$ to $\mathrm{cm}$ ) are often excluded from the current definition of SGD and referred to as "porewater exchange"(Moore, 2010; Santos et al., 2012). For the purpose of this study, we prefer distinguishing exchange processes depending on their origin, composition and driving force, rather than differentiating them according to their length-scale. Therefore, the term karstic groundwater discharge is used for low-salinity groundwater driven by the terrestrial hydraulic gradient, whereas recirculation fluxes refer to both short- and long-scale recirculation of saline water through sediments, which is driven by pressure gradients forced by tides, waves, bottom currents, benthic organisms, or bottom water / porewater density changes (Huettel et al., 2014; Santos et al., 2012).

\section{STUDY SITE}

La Palme lagoon lies on the western French Mediterranean coastline and is well recognized for its high conservation value and its high biodiversity (it is included under the international Ramsar Convention and the environmental protection program Natura2000) (Fig 1). The lagoon has a surface area of 500 ha and mean and maximum water depths of $\sim 0.7$ and $\sim 2 \mathrm{~m}$, respectively. It is partially connected with the Mediterranean Sea through a small opening in the coastal sand spit (usually $<10 \mathrm{~m}$ width and $<1 \mathrm{~m}$ depth), which is seasonally closed (particularly during summer months). A road dike and a railway dike separate the lagoon into three basins (northern, central and southern) and further restrict the exchange between lagoon waters and the sea, allowing exchange between sections only through one small bridge in each dike (Fig. 1). The study site experiences rainfall 
during fall and spring and little rain during summer (total precipitation of 310 and $440 \mathrm{~mm}$ in 2016 and 2017, respectively) (Fig. 2).

Karstified Jurassic and Lower Cretaceous limestones constitute the main aquifer of the area (Wilke and Boutière, 2000). Groundwater from this aquifer discharges directly to the northern section of La Palme lagoon year-round through karst conduits (Wilke and Boutière, 2000). Total karstic groundwater inputs to La Palme lagoon are estimated to be on the order of $10^{4} \mathrm{~m}^{3} \mathrm{~d}^{-1}$ and have been shown to contribute to maintaining transitional (brackish) ecosystem functioning throughout the year (Stieglitz et al., 2013a; Wilke and Boutière, 2000). A karstic spring that feeds a nearby ancient wash basin ("lavoir") and flows to the lagoon through a perennial stream (spring in Fig. 1) represents the main karstic groundwater source (accounting for $\sim 50 \%$ of groundwater inputs; Wilke and Boutière, 2000). A few small streams also drain freshwater into the lagoon from a relatively small catchment area mainly composed by Quaternary alluvial deposits, but they flow only during rainfall periods. Total water inputs from these streams are estimated to be significantly smaller (more than one order of magnitude smaller) than inflows from karstic groundwaters (Wilke and Boutière, 2000). Considering that the streams were not flowing during the samplings conducted, inputs from the streams are considered negligible for the purpose of this study. A sewage treatment plant discharges treated wastewater $\left(\sim 10^{2} \mathrm{~m}^{3} \mathrm{~d}^{-1}\right)$ into the northern part of the lagoon (Fig. 1). Recent studies have demonstrated that large amounts of lagoon water recirculate through permeable sediments in La Palme lagoon (Stieglitz et al., 2013b; Tamborski et al., submitted). Estimated recirculation flows in summer periods are on the order of $3 \cdot 10^{4}-2 \cdot 10^{5} \mathrm{~m}^{3} \mathrm{~d}^{-1}$, which is the 
equivalent of the volume of the entire lagoon recirculating through the sediments every 25 days (Stieglitz et al., 2013a).

The internal mixing of the lagoon and its exchange with coastal waters is driven primarily by the strong north-westerly winds characteristic of the region (regularly exceeding $10 \mathrm{~m} \mathrm{~s}^{-1}$, particularly in winter). Tidal forcing plays a minor role in the hydrodynamic functioning of this lagoon, since tidal variations in the Mediterranean Sea are usually less than $0.4 \mathrm{~m}$ and exchange between the lagoon and the sea is highly restricted. The lagoon is vertically well mixed due to its shallowness and wind-driven mixing. The dynamic interplay between fresh water inputs, the two-way exchange between lagoon waters and the sea and seasonally changing evaporation results in significant seasonal changes in water levels and salinities (Fig 2). Sediments throughout most of the northern basin are fine-tocoarse grained sands $(100-500 \mu \mathrm{m})$ with the northern part of this basin dominated by fine-grained sediments $(\sim 50 \mu \mathrm{m})$ (IFREMER, 2003).

The present study is focused on the northern basin of La Palme Lagoon, which represents the main water body $(\sim 85 \%$ of the total lagoon area; $>95 \%$ of the total lagoon water volume) and receives all of the groundwater inputs from karstic springs.

\section{THEORY}

The magnitude of karstic groundwater- and recirculation-driven nutrient fluxes was estimated through a radon-based approach. Radon $\left({ }^{222} \mathrm{Rn}\right)$ is a natural environmental tracer that has been widely used for quantifying groundwater 
inflows (both terrestrial and recirculation flows, usually in combination) (e.g. Burnett and Dulaiova, 2003; Cook et al., 2006; Rodellas et al., 2012; Stieglitz et al., 2010). Radon is a radioactive (half-life of 3.8 days) inert gas that is produced from the decay of ${ }^{226} \mathrm{Ra}$, mainly associated with sediment and aquifer solids. Radon tends to be depleted in surface waters due to gaseous exchange with the atmosphere and radioactive decay, so that radon concentrations in groundwater and sediment porewaters are elevated relative to surface waters by 2-3 orders of magnitude.

\section{1. Concurrent water and radon mass balances for surface waters}

Following Stieglitz et al (2013a), mass balances for water and radon were constructed to simultaneously estimate karstic groundwater discharge and saline recirculation water flows to the northern basin of La Palme lagoon.

The surface water mass balance for the northern basin of La Palme lagoon is:

$$
\frac{\partial V_{N}}{\partial t}=Q_{g}+P A_{N}-E A_{N}-Q_{N C}
$$

where $V_{N}$ and $A_{N}$ are the water volume $\left[\mathrm{m}^{3}\right]$ and surface area $\left[\mathrm{m}^{2}\right]$ of the northern basin, respectively, $Q_{g}$ is the karstic groundwater discharge $\left[\mathrm{m}^{3} \mathrm{~d}^{-1}\right], P$ and $E$ are the precipitation and evaporation rates $\left[\mathrm{m} \mathrm{d}^{-1}\right]$, respectively, $Q_{N C}$ is the water flow from the northern to the central basin of the lagoon $\left[\mathrm{m}^{3} \mathrm{~d}^{-1}\right]$ (negative flows indicate inputs from the central basin) and $t$ is time [d].

The radon mass balance for the northern basin of La Palme lagoon is:

$$
\frac{\partial C V_{N}}{\partial t}=Q_{g} C_{g}+\lambda V_{N} C_{R a}+\left(F_{\text {diff }}+F_{\text {recir }}\right) A_{N}-k A_{N}\left(C-\alpha C_{\text {air }}\right)-\lambda V_{N} C-Q_{N C} C-D_{N C} \Delta C
$$


where $C$ and $C_{g}$ are the mean concentration of radon in the northern basin and in karstic groundwater [Bq m${ }^{-3}$, respectively, $C_{R a}$ is the mean concentration of ${ }^{226} \mathrm{Ra}$ in the northern basin $\left[\mathrm{Bq} \mathrm{m}^{-3}\right], F_{\text {diff }}$ and $F_{\text {recir }}$ are the net fluxes of radon per unit area from underlying lagoon sediments due to molecular diffusion and lagoon water recirculation $\left[\mathrm{Bq} \mathrm{m} \mathrm{m}^{-2} \mathrm{~d}^{-1}\right]$, respectively, $\lambda$ is the radioactive decay constant of radon $\left[\mathrm{d}^{-1}\right], k$ is the gas transfer velocity $\left[\mathrm{m} \mathrm{d}^{-1}\right], C_{\text {air }}$ the radon concentration in air $\left[\mathrm{Bq} \mathrm{m}^{-3}\right]$ and $\alpha$ the air-water partitioning of radon corrected for salinity and temperature (Schubert et al., 2012b), $D_{N C}$ is the dispersive exchange flux of radon between the northern and the central basins of the lagoon $\left[\mathrm{m}^{3} \mathrm{~d}^{-1}\right]$, and $\Delta C$ is the difference in radon concentrations at the boundary between northern and central basins $\left[\mathrm{Bq} \mathrm{m}{ }^{-3}\right]$. Notice that if $Q_{N C}$ is negative, the mean radon concentration from the central basin should be used as $C$ in the term $Q_{N C} C$. The term $\alpha C_{a i r}$ can be neglected in comparison to $C$. Stieglitz et al. (2013a) showed that radon exchange fluxes between the northern and central basins (including advective and dispersive fluxes) account for less than $1 \%$ of total radon outputs, and thus the terms $Q_{N C} C$ and $D_{N C} \Delta C$ are neglected for the radon mass balance. The simplified equation used in this study is thus:

$$
\frac{\partial C V_{N}}{\partial t}=Q_{g} C_{g}+\lambda V_{N} C_{R a}+\left(F_{\text {diff }}+F_{\text {recir }}\right) A_{N}-k A_{N} C-\lambda V_{N} C
$$

\section{METHODS}

\subsection{Porewater collection and analysis}

Seasonal surveys were conducted in June 2016, November 2016, April 2017 and June 2017. During each survey, porewater samples for radon, salinity and nutrient analysis were collected at 3 different locations (Pz1, Pz2 and Pz3; Fig. 1) using a direct-push, shielded-screen well-point piezometer (Charette and Allen, 2006). 
These locations were chosen to be representative of the different types of sediments in the lagoon. Whereas Pz2 is not located in the northern section of the lagoon, sediments from Pz2 have the same characteristics as sediments from the southern part of the northern basin, and thus this location is considered as representative of this area. A fourth location (Pz4; Fig. 1) was also selected as representative of fine-grained sediment areas, but porewater samples could not be collected due to the low hydraulic conductivities of the clay sediments. At each one of the three locations, porewater samples were collected at depths of $5,10,15,20$, 30,50 and $80 \mathrm{~cm}$ below the sediment-water interface. For radon analysis, $10-\mathrm{mL}$ of filtered $(0.8 \mu \mathrm{m})$ porewater was collected at each depth using a gas-tight syringe coupled to the piezometer tubing and directly transferred to 20 -mL vials prefilled with a 10 -mL high-efficiency mineral oil scintillation cocktail, while minimizing water-air contact (Cable and Martin, 2008). Concentrations of radon were analyzed by liquid scintillation counting on a Quantulus 1220 with alpha-beta discrimination counting (background of 0.2-0.4 cpm; efficiency of 1.6-2.2, depending on the quenching factor of the sample). Samples for salinity analysis (10 $\mathrm{mL}$ ) were also collected at each depth and measured using a pre-calibrated WTW multiparameter sonde (WTW Multi 3430 meter with TetraCon ${ }^{\circledR} 925$ probe for conductivity and temperature measurements). For nutrient analysis (ammonium $\left(\mathrm{NH}_{4}{ }^{+}\right)$, nitrate $\left(\mathrm{NO}_{3}{ }^{-}\right)$and phosphate $\left.\left(\mathrm{PO}_{4}{ }^{3-}\right)\right), 20 \mathrm{~mL}$ of filtered $(0.7 \mu \mathrm{m})$ porewater was collected at each depth in acid-clean vials. Nutrient samples were preserved with $\mathrm{HgCl}_{2}\left(6 \mathrm{~g} \mathrm{l}^{-1}\right)$ to prevent bacterial activity (Kirkwood, 1992). $\mathrm{NO}_{3}{ }^{-}$and $\mathrm{PO}_{4}^{3-}$ concentrations were measured by colorimetric methods using a Technicon AutoAnalyser® II with detection limits of $0.05 \mu \mathrm{mol} \mathrm{L}^{-1}$ and $0.02 \mu \mathrm{mol} \mathrm{L}^{-1}$ for $\mathrm{NO}_{3}{ }^{-}$ and $\mathrm{PO}_{4}{ }^{3-}$, respectively (Aminot and Kérouel, 2007; Raimbault et al., 1990). $\mathrm{NH}_{4}{ }^{+}$ 
concentrations were determined on dilute samples ( 4 to 10 times) with a Turner Designs TD-700 Fluorometer (detection limit: $0.05 \mu$ mol L-1) (Holmes et al., 1999).

\subsection{Surface water collection and analysis}

During each sampling campaign, the spatial distribution of radon and salinity in lagoon waters from the northern section of the lagoon was investigated by continuously measuring these parameters from a moving boat. For radon counting, two electronic radon-in-air monitors RAD7 (Durridge) were connected in parallel and coupled to a gas exchange membrane (Liqui-Cel MiniModule; Dulaiova et al., 2005; Schubert et al., 2012a). Surface water was pumped with a submersible pump directly to the membrane, where equilibrium was established between the dissolved radon in continuously pumped lagoon water and radon in a closed air loop that circulates through the monitors. Radon concentration in water was determined from the measured concentration in air, by using the air-water partitioning of radon corrected for water salinity and temperature (Schubert et al., $2012 \mathrm{~b}$ ). The small lag time produced by radon extraction and radioactive counting was corrected following (Stieglitz et al., 2010). Surface water salinity and temperature were measured using the WTW multiparameter sonde (Multi 3430 meter and TetraCon® 925 probe). Measured radon concentrations and salinities were interpolated by kriging at $50 \mathrm{~m}$ spatial resolution to obtain distribution grids and weighted-average concentrations. For radon, the analytical uncertainty $(1 \sigma)$ was also taken into account to derive grids of minimum and maximum radon concentrations, which were used to estimate the uncertainties associated with average radon concentrations. Radon data points ( $n>40$ for each survey) were spatially well distributed in the northern basin of the lagoon and thus we assume 
that uncertainties derived from spatial interpolation are smaller than analytical uncertainties (relative uncertainties for $C$ of 20-30\%, depending on the survey). The application of different interpolation methods (Inverse Distance Weighted and Triangulated Irregular Network) resulted in similar average radon concentrations to those obtained by kriging ( $<10 \%$ of difference between interpolation methods).

Radon and nutrient samples were also collected from the sewage effluent, the main karstic groundwater spring and from surface waters $(\sim 10 \mathrm{~cm}$ above the sedimentwater interface) at the three piezometer locations (Pz1, Pz2 and Pz3; Fig. 1). Additional nutrient samples were collected throughout the lagoon (5-10 samples/survey) to obtain a qualitative distribution of nutrients in surface waters. Radon samples (2 L) were collected using a small submersible pump to minimize gas loss and analyzed using the radon-in-air monitor RAD7 coupled to a gas extraction accessory for bottles (Durridge Inc). Radon samples in surface waters were counted twice: just after sample collection to determine dissolved radon and after aging for a minimum of 4 weeks to estimate the ${ }^{226} \mathrm{Ra}$ dissolved in surface waters. Nutrient samples were collected with a 1-L acid-clean Nalgene bottle and analysed as described above. Temperatures and salinities were measured in situ in groundwater, sewage effluent and surface waters using the WTW multiparameter sonde (Multi 3430 meter and TetraCon® 925 probe).

\subsection{Ancillary measurements and analysis}

A detailed bathymetry map for the northern section of the lagoon was constructed by interpolating echosounder/DGPS data collected in December 2016 to $50 \mathrm{~m}$ spatial resolution. To estimate the water volumes of the lagoon for the different 
campaigns, the bathymetry grid was corrected for changes in water level estimated from water depth measurements throughout the lagoon at each sampling ( $\mathrm{n}>20$ for each sampling). The corrected bathymetry grids for each campaign, together with the radon concentration and salinity grids, were used to obtain volume-weighted average radon concentration and salinity values for the northern section of the lagoon.

Lagoon water level was recorded continuously at 10 min intervals using HOBO pressure transducers installed at 3 sites of the northern part of the lagoon (Pz1, Pz3 and Pz4) from 1 April 2017 to 28 April 2017 and from 9 June 2017 to 4 July 2017. Recorded pressures were corrected for atmospheric variation and used to estimate the variation of lagoon water depth over time for the April 2017 and June 2017 campaigns. Additionally, a drag-tilt current meter (Marotte HS) was installed under the railway bridge in June 2017 to estimate the magnitude of water flows exchanged between northern and central basins. Exchanged daily water flows were obtained from current measurements recorded every 5 minutes and the exchange section of the bridge (17 $\mathrm{m}^{2}$; Fiandrino et al., 2012). Hourly rainfall, temperature and wind data at the nearby meteorological station "Leucate" was extracted from the database of the French meteorological service (Météo France). Monthly data on lagoon water levels and salinity at three sites in the northern lagoon (PN stations in Fig. 1), as well as water estimated inflows from the sewage treatment plant, were obtained from the database of the "Parc Naturel Régional de la Narbonnaise en Méditerranée" (PNRNM) (Fig. 2).

\subsection{Radon equilibration experiment}


Four sediment cores of $\sim 30 \mathrm{~cm}$ length were collected at sites Pz1, Pz2, Pz3 and Pz4

(Fig. 1) to estimate the production of radon from sediments. The cores were sliced at $5 \mathrm{~cm}$ intervals and the sections of 5-10, 15-20 and 25-30 $\mathrm{cm}$ from each site were used for sediment equilibration experiments (Corbett et al., 1998). Ca. $200 \mathrm{~g}$ of dry sediment was put into $500 \mathrm{~mL}$ bottles and the remaining volume was filled with Ra-free lagoon water (Ra removed by using acrylic fiber impregnated with $\mathrm{MnO}_{2}$; Moore and Reid, 1973). The bottles containing the sediments (hermetically sealed) were stored for more than 1 month and periodically shaken. The radon concentration in water was directly measured using the RAD7 coupled to the gas extraction accessory for bottles and the results were corrected to the specific ratio porewater/solids in sediments (Stieglitz et al., 2013a). The average radon concentration from the three sections at each site is used to represent the porewater radon concentration in equilibrium with sediments.

\section{RESULTS}

\subsection{Porewater profiles}

Porewater could be easily sampled with a push-point piezometer from most of the depths at the locations Pz1, Pz2 and Pz3, indicating a relatively high hydraulic permeability for the sandy sediments at these locations. The only exception was a relatively impermeable layer found at Pz3, extending from $\sim 30$ to $\sim 40 \mathrm{~cm}$ below the sediment-water interface. Porewater samples could not be collected from Pz4 due to the low hydraulic conductivities of the clay sediments from this location.

Porewater salinity depth profiles reflected mixing between two endmembers: i) lagoon water with varying salinities depending on the season and the location (e.g. 
Fig. 2), and ii) deep, evaporative, hypersaline (salinity up to 80) porewater (Fig. 3). Most of the vertical porewater profiles displayed an increase in salinities downward, showing different trends in different locations and seasons depending on the dynamics of the mixing between these two endmembers. Porewaters were significantly enriched in radon (maximum concentration of $6800 \pm 600,4600 \pm$ 400 and $8000 \pm 900 \mathrm{~Bq} \mathrm{~m}^{-3}$ in Pz1, Pz2 and Pz3, respectively) relative to surface waters $\left(20-200 \mathrm{~Bq} \mathrm{~m}^{-3}\right)$, mainly as a consequence of radon production from ${ }^{226} \mathrm{Ra}$ in sediments and the lack of atmospheric evasion (Fig. 3). A deficit of in situ porewater radon concentrations relative to radon in equilibrium with sediments (derived from sediment equilibration experiments; Fig. 3) was generally observed for the upper sediments, indicating radon exchange between porewaters and overlying lagoon waters due to radon diffusion or/and water advection (i.e. water recirculation).

Porewater concentrations of $\mathrm{NH}_{4}{ }^{+}$and, to a lesser extent, $\mathrm{PO}_{4}{ }^{3-}$ were significantly enriched relative to lagoon waters (20- and 5-fold on average, respectively), with concentrations generally increasing with depth (Fig. 4). In contrast, concentrations of $\mathrm{NO}_{3}{ }^{-}$in porewaters were comparable or even lower than those measured in overlying waters. No clear seasonal patterns were observed for any of the analyzed dissolved nutrients in porewaters.

\subsection{Radon and salinity distributions in lagoon surface waters}

The highest radon concentrations (higher than $300 \mathrm{~Bq} \mathrm{~m}^{-3}$ in June 2016) and lowest salinities (down to 17, in April 2017) occurred in the far north of the lagoon, with radon concentrations decreasing and salinities increasing southwards 
(Fig. 5). This distribution indicates the presence of low-salinity, high-radon sources in the north of the lagoon, coinciding with the main karstic spring, and agrees well with previous observations from Stieglitz et al. (2013a). The lagoon water volume (i.e. water depth) varied significantly through the year, with lower water volumes in summer when evaporative loss exceeded water input (e.g. estimated water volume of $2.5 \cdot 10^{6} \mathrm{~m}^{3}$ in June 2016) and maximum values in the wet season (e.g. 5.3·106 $\mathrm{m}^{3}$ in November 2016) (Fig. 2; Fig 5; Table 1). The seasonal evolution of salinity also reflected the annual variations on low-salinity water inputs and evaporation rates (Fig. 2; Fig. 5). Salinity was at a maximum in summer 2016 (average salinity of 37 in June 2016), decreasing significantly during the wet season (salinities of 32 and 18 in November 2016 and April 2017, respectively), and increasing again at the end of spring due to a reduction in lowsalinity inputs and an increase in evaporation rates (average salinity of 23 in June 2017) (Fig. 2; Fig. 5). Radon concentrations were also maximal in summer campaigns (average concentrations of $120 \pm 20$ and $93 \pm 24 \mathrm{~Bq} \mathrm{~m}^{-3}$ for June 2016 and June 2017, respectively), whereas the lowest concentrations were measured in November 2016 (23 $\pm 7 \mathrm{~Bq} \mathrm{~m}^{-3}$ ) (Table 1). While the salinity of the lagoon largely represents a balance between the rate of freshwater inputs and evaporation, the radon concentration is highly influenced by recirculation inputs (which do not affect salinity, as they do not represent a net water flux) and the wind speed (which affects the gas exchange rate). For these reasons, the seasonal variability of salinity and radon concentrations do not necessarily coincide. Additionally, while the radon activity reflects the water balance over the few days prior to sampling, salinity reflects lagoon dynamics over a much longer time period (see section 5.4). 
Groundwater discharging from the main karstic spring was brackish (salinity 5.0 to 9.4, depending on the season), presumably reflecting some degree of interaction between fresh groundwater and seawater in the coastal aquifer. Radon concentration in the karstic spring was constant throughout the year and significantly enriched relative to lagoon waters, with values ranging from $2290 \pm$ 90 to $2600 \pm 110 \mathrm{~Bq} \mathrm{~m}^{-3}$. Radon concentrations measured in the sewage effluent were on the order of $20 \mathrm{~Bq} \mathrm{~m}^{-3}$, and thus this source is hereafter neglected.

\subsection{Nutrients in lagoon surface waters}

$\mathrm{NO}_{3}-$ concentrations were significantly higher in the karstic groundwater spring $\left(50-62 \mu \mathrm{mol} \mathrm{L}^{-1}\right)$ and in the sewage effluent $\left(100-520 \mu \mathrm{mol} \mathrm{L}^{-1}\right)$ than in lagoon waters (0.1 - $65 \mu \mathrm{mol} \mathrm{L}{ }^{-1}$ ) (Fig. 6). The decrease of $\mathrm{NO}_{3}{ }^{-}$concentrations with increasing salinity observed in lagoon waters (Fig. 6) clearly indicates a lowsalinity source of $\mathrm{NO}_{3}$ - (sewage effluent and/or groundwater spring) and a diminution of concentrations due to mixing with $\mathrm{NO}_{3}^{-}$-poor lagoon waters and $\mathrm{NO}_{3}^{-}$ removal chiefly due to biological uptake (Capone, 2008). No clear nutrient patterns were observed for $\mathrm{NH}_{4}{ }^{+}$and $\mathrm{PO}_{4}^{3-}$ vs salinity (Fig. 6). Concentrations of $\mathrm{NH}_{4}{ }^{+}$in the karstic groundwater spring $\left(0.1-0.5 \mu \mathrm{mol} \mathrm{L}^{-1}\right)$ and in the sewage effluent $(2.6-16$ $\mu \mathrm{mol} \mathrm{L}-1)$ were lower or comparable to concentrations in lagoon waters $[0.8-36$ $\mu \mathrm{mol} \mathrm{L}-1)$, whereas $\mathrm{PO}_{4}{ }^{3-}$ concentrations in the sewage effluent $(22-71 \mu \mathrm{mol} \mathrm{L}-1)$ were significantly higher than concentrations in both karstic groundwaters $(0.1$ $0.4 \mu \mathrm{mol} \mathrm{L}-1)$ and lagoon waters $(0.1-2.5 \mu \mathrm{mol} \mathrm{L}-1)$. The low $\mathrm{NH}_{4}{ }^{+}$and $\mathrm{PO}_{4}{ }^{3-}$ concentrations measured in karstic groundwater and in the sewage effluent (only for $\mathrm{NH}_{4}^{+}$), together with the lack of any clear nutrient-salinity pattern (Fig. 6), suggest that neither the karstic spring nor the sewage effluent are significant 
sources of these nutrients to lagoon waters. Relatively high concentrations for both $\mathrm{NH}_{4}{ }^{+}$and $\mathrm{PO}_{4}{ }^{3-}$ were indeed measured at mid to high salinity lagoon waters, corresponding to areas far from both the sewage and karstic groundwater inputs. This distribution suggests that there is either production of $\mathrm{NH}_{4}{ }^{+}$and $\mathrm{PO}_{4}{ }^{3-}$ in the water column, which is unlikely given its aerobic nature (Christensen et al., 2000), or an additional source of these nutrients, most likely inputs from sediments due to diffusion and/or lagoon water recirculation.

\subsection{Estimation of karstic groundwater and recirculation inputs from water and radon mass balances}

Water (Eq. 1) and radon (Eq. 3) mass balance equations were solved analytically for the four seasonal samplings, and uncertainties were propagated throughout each term. The values used and the approach followed to estimate all terms in the water (Eq. 1) and radon (Eq. 3) mass balances are described in the following sections (5.4.1 - 5.4.2) and summarized in Table 1 and Table 2.

\subsubsection{Water mass balance}

The terms in the water mass balance were estimated for a period of 30 days prior to the surveys, and thus karstic groundwater estimates represent average water flows for the same period of time. Water levels measured continuously for $\sim 1$ month in April 2017 and June 2017 (Fig. 7) were used to estimate the water volume change over time $\left(\frac{\partial V_{N}}{\partial t}\right)$ for April 2017 and June 2017 campaigns. The trend derived from monthly measurements of water level at 2 different stations in the northern lagoon (PN1 and PN3; Fig. 2) was used as estimate for $\frac{\partial V_{N}}{\partial t}$ for June 2016 
and November 2016 campaigns. The Penman equation was used to estimate evaporation rates $(E)$ from air temperature, wind speed, relative humidity and net solar irradiance (Penman, 1948). This equation has already been tested and applied in similar lagoons on the French Mediterranean coastline (IFREMER, 2010). Following Stieglitz et al. (2013a) and assuming that the exchange between the lagoon and the sea is negligible and the volume of the southern and central basins is relatively constant over time, the water flow from the northern section of La Palme lagoon to the central basin $\left(Q_{N C}\right)$ equals the total evaporative loss minus precipitation in the central and southern basins $\left(Q_{N C}=(E-P) \cdot A_{C+S}\right)$. Estimated $Q_{N C}$ water flows are on the order of $(1-4) \cdot 10^{3} \mathrm{~m}^{3} \mathrm{~d}^{-1}$, which are in relatively good agreement with the estimated water flows for June 2017 using the drag-tilt current meter installed under the railway bridge (average of $\left.(1 \pm 7) \cdot 10^{3} \mathrm{~m}^{3} \mathrm{~d}^{-1}\right)$.

By solving Eq. 1 for each survey, karstic groundwater flow to La Palme lagoon $\left(Q_{g}\right)$ is estimated to range from $(3 \pm 15) \cdot 10^{3} \mathrm{~m}^{3} \mathrm{~d}^{-1}$ in June 2016 to $(25 \pm 9) \cdot 10^{3} \mathrm{~m}^{3} \mathrm{~d}^{-1}$ in November 2016 (Table 1). These flows are in good agreement with previous estimates of karstic groundwater flows into La Palme lagoon (Stieglitz et al., 2013a; Wilke and Boutière, 2000). The estimated groundwater flows have large uncertainties (relative uncertainties sometimes higher than 100\%), which are mainly derived from the assumed uncertainty of $50 \%$ associated with $\frac{\partial V_{N}}{\partial t}$, and make difficult to evaluate the seasonal variability of groundwater inputs. However, as previously observed by Wilke and Boutière (2000), karstic groundwater inputs into La Palme lagoon during the wet season (November 16 and April 17) are consistently higher than during the dry season (June 16 and June 17). This seasonal variability in karstic groundwater inputs is likely linked to variations on 
the terrestrial hydraulic gradient, as commonly observed in groundwater studies in coastal systems (Garcia-Solsona et al., 2010; Holliday et al., 2007; Rodellas et al., 2012; Smith et al., 2008).

\subsubsection{Radon mass balance}

In a system with reduced exchange with offshore waters, the rate of radon decrease from the water column will follow $e^{-\left(\lambda t+\frac{k}{h} t\right)}$, where $\lambda$ is the radon decay constant $\left(0.181 \mathrm{~d}^{-1}\right), t$ is the time, $k$ is the radon gas transfer velocity and $h$ the water depth. Considering an average $k$ and $h$ of $1.3 \mathrm{~m} \mathrm{~d}^{-1}$ and $0.9 \mathrm{~m}$ for La Palme lagoon, respectively (Table 1), less than $5 \%$ of the initial radon inventory would remain in the system after 2 days. Therefore, unlike the water mass balance, radon concentrations measured in the lagoon during the different surveys mainly reflected the dynamics of radon inputs and outputs during the 48 hours previous to the sampling. Provided that there are no abrupt changes in wind regimes during these previous hours, it is thus reasonable to assume relatively constant radon inventories during these 2-day periods (i.e. $\frac{\partial C V_{N}}{\partial t}=0$ ) (see section 6.1. for further discussion).

$Q_{g w}$ was estimated in the water mass balance as the average karstic groundwater flow for the month previous to the survey. By using these estimates in the radon mass balance we are implicitly assuming that $Q_{g w}$ is constant during these periods and thus representative of groundwater inputs during the 48 hours previous to the sampling. 
The diffusive flux of radon from sediments $\left(F_{\text {diff }}\right)$ was estimated from a depthindependent approach following (Cook et al., 2008; Martens et al., 1980):

$$
F_{\text {diff }}=\left(c_{e q}-c_{L}\right) \sqrt{\lambda \theta D_{s}}
$$

where $\theta$ is sediment porosity, $D_{s}$ is the diffusion coefficient of radon in sediments and $c_{e q}$ and $c_{L}$ are radon concentration in equilibrium with sediments and in lagoon water, respectively. $D_{s}$ was estimated as a function of temperature (T) and corrected for tortuosity $\left(D_{s}=\theta(10-[(980 / T)+1.59]\right.$; Peng et al., 1974; Ullman and Aller, 1982). A sediment porosity of $0.47,0.43,0.39$ and 0.71 was used or Pz1, Pz2, Pz3 and Pz4, respectively, as estimated in a concurrent study in La Palme lagoon (Tamborski et al., submitted). $c_{e q}$ was derived from equilibration experiments (depth-averaged radon equilibrium concentration of $4700 \pm 900,3400 \pm 500,7600$ \pm 1100 and $5500 \pm 900 \mathrm{~Bq} \mathrm{~m}^{-3}$ for Pz1, Pz2, Pz3 and Pz4, respectively) and $c_{L}$ was considered negligible in comparison with $c_{e q}$. According to the distribution of surficial sediments in La Palme lagoon (IFREMER, 2003), we assumed that results obtained from Pz1, Pz2, Pz3 and Pz4 are representative of 20\%, 15\%, 40\% and $25 \%$ (assumed absolute uncertainty of $\pm 5 \%$ ), respectively, of the total sediment surface area of the northern basin of La Palme lagoon, resulting in average radon diffusion fluxes on the order of $10-15 \mathrm{~Bq} \mathrm{~m}^{-2} \mathrm{~d}^{-1}$. Dissolved ${ }^{226} \mathrm{Ra}$ concentration measured in lagoon waters ranged from 10 to $50 \mathrm{~Bq} \mathrm{~m}^{-3}$, in good agreement with previous estimates for La Palme lagoon (Stieglitz et al., 2013a).

Wind-dependent gas transfer velocities $(k)$ were estimated from the empirical equation of (MacIntyre et al., 1995), normalized for radon in seawater and the specific water temperature at each sampling (Wanninkhof, 2014):

$$
k_{(\mathrm{cm} / \mathrm{h})}=0.45 u^{1.6}\left(\frac{S c}{660}\right)^{0.5}
$$


where $u$ is the wind speed [m s$\left.{ }^{-1}\right], S c$ is the Schmidt number for radon at a given temperature (Wanninkhof, 2014), and $k_{(\mathrm{cm} / \mathrm{h})}$ is the gas transfer velocity in [ $\mathrm{cm} \mathrm{h}^{-1}$ ]. To obtain a representative $k$ value for each seasonal sampling, we used the wind speed ( \pm its uncertainty) that covers the range comprised between the $1^{\text {st }}$ and $3^{\text {rd }}$ quartiles of all the hourly wind measurements during the 48-h previous to the sampling. Wind speeds ranged from $2.0 \pm 0.3 \mathrm{~m} \mathrm{~s}^{-1}$ in June 2017 to $9.9 \pm 2.1 \mathrm{~m} \mathrm{~s}^{-1} \mathrm{in}$ November 2016, resulting in estimates of $k$ ranging from $0.3 \pm 0.1$ to $3.1 \pm 1.0 \mathrm{~m} \mathrm{~d}^{-1}$ (Table 1). The uncertainties associated with these estimates are derived from the variation of wind speeds, and thus, they do not take into account uncertainties associated with the empirical equation to estimate $k$ (see section 6.1).

The net flux of radon driven by recirculation of lagoon water through sediments $\left(F_{\text {recirc }}\right)$ can be estimated by solving Eq. 3, resulting in radon fluxes ranging from 35 \pm 16 to $57 \pm 39 \mathrm{~Bq} \mathrm{~m}^{-2} \mathrm{~d}^{-1}$. These radon fluxes are in good agreement with the previous estimates for La Palme lagoon in summer of 17-66 $\mathrm{Bq} \mathrm{m}^{-2} \mathrm{~d}^{-1}$ (Stieglitz et al., 2013a). Net fluxes of radon driven by recirculation of lagoon water through sediment for the different samplings are similar and do not show any seasonal pattern, partially due to the large relative uncertainties associated with these estimates.

\subsubsection{Recirculation water flows to La Palme lagoon}

Volumetric flows of lagoon water recirculating through sediments can be obtained by dividing the radon flux by the radon concentration in porewaters inflowing to the lagoon, i.e. the recirculation endmember. The radon concentration of the recirculation endmember is the concentration in porewaters immediately below 
the sediment-water interface (subtracting the concentration in overlying waters) (Cook et al., 2018a, 2018b). We thus used the radon concentration from the shallowest porewater sample from each piezometer, which was collected at $5 \mathrm{~cm}$ from the sediment-water interface. An average radon concentration for the recirculation endmember was obtained for each sampling period by areaweighting the concentrations in the different piezometers according to their spatial representativeness.

The estimated water flows of lagoon water recirculating through sediments derived from the radon mass balance to the northern section of La Palme lagoon range from $(42 \pm 33) \cdot 10^{3}$ to $(89 \pm 44) \cdot 10^{3} \mathrm{~m}^{3} \mathrm{~d}^{-1}$ and are summarized in Table 3 . These flows are in good agreement with previous estimates of recirculation flows in La Palme lagoon from tracer-derived approaches (Stieglitz et al., 2013a; Tamborski et al., submitted), which were only focused on the summer season. Recirculation flows estimated here are significantly higher than karstic groundwater inputs (Table 3) and are equivalent to 0.5 - $5 \%$ of lagoon water volume recirculating through bottom-sediments every day.

\subsection{Nutrient fluxes from karstic groundwater and recirculation}

The most commonly applied approach to estimate groundwater-driven nutrient fluxes to a surface water body is to multiply the water flow by the representative concentration in the groundwater endmember (Charette and Buesseler, 2004; Liu et al., 2012; Santos et al., 2008; Tovar-Sánchez et al., 2014). The karstic spring inflowing to La Palme lagoon can be directly sampled and therefore the nutrient fluxes driven by karstic groundwater discharge can be accurately estimated (Table 
3). Given that the nutrient concentrations in the spring were relatively constant throughout the year, these fluxes follow the same seasonal pattern as groundwater flows, with maximum fluxes of $\mathrm{NO}_{3}{ }^{-}, \mathrm{NH}_{4}{ }^{+}$and $\mathrm{PO}_{4}{ }^{3-}$ of $1200 \pm 400,12 \pm 4$ and $8.7 \pm$ $3.0 \mathrm{~mol} \mathrm{~d}^{-1}$ in November 2016 (Table 3).

The recirculation-driven nutrient inputs were estimated from the recirculationdriven radon flux and the excess (in relation to overlying water) ratio of nutrient over radon concentrations in porewaters. Excess ratios from samples collected at 5 cm below the sediment-water interface at each piezometer were averaged considering their spatial representativeness to obtain an average excess ratio for each sampling period. Estimated net nutrient fluxes driven by lagoon water recirculation to La Palme lagoon (Table 3) are on the order of $1900-5500 \mathrm{~mol} \mathrm{~d}^{-1}$ for $\mathrm{NH}_{4}{ }^{+}$and $22-71 \mathrm{~mol} \mathrm{~d}^{-1}$ for $\mathrm{PO}_{4}{ }^{3-} . \mathrm{NO}_{3}{ }^{-}$concentrations in porewaters are comparable or lower than in overlying waters, suggesting that recirculation of lagoon water in La Palme lagoon is not a relevant source of $\mathrm{NO}_{3}{ }^{-}$and it could act mainly as a sink.

\section{DISCUSSION}

\subsection{Uncertainties on estimated radon, water and nutrient fluxes from recirculation}

\subsubsection{Uncertainties on net radon fluxes from recirculation}

The uncertainties associated with net radon fluxes via recirculation derived from the mass balance approach (Table 1, Table 2) largely depend on the accuracy of determining those input and output terms with a high relative contribution to the mass balance. Lagoon water recirculation is the largest source of radon to La 
Palme lagoon (accounting for $>60 \%$ of total inputs; Table 1). The second most relevant source is radon diffusion from sediments, which accounts for $15-25 \%$ of total inputs. Estimated radon diffusive fluxes are in good agreement with previous estimates in La Palme obtained via alternative approaches (Stieglitz et al., 2013a), suggesting that this input term is relatively well constrained. Potential errors in estimating the other radon source terms (karstic groundwater inputs and production from ${ }^{226} \mathrm{Ra}$ decay) have a small influence on final radon budget estimates and uncertainties.

Radon evasion to the atmosphere $(60-90 \%$ of total outputs) and radon decay (5$40 \%)$ are the main radon output terms. Recirculation-driven radon flux estimates are thus highly sensitive to $k$ and $C$, and thus, on the uncertainties associated with these terms. By selecting wide uncertainties of wind speeds ( $u$ covering the values between $1^{\text {st }}$ and $3^{\text {rd }}$ quartiles of wind data during the 48 -h prior to sampling) and radon concentration in lagoon waters (covering the range between maximum and minimum $C$ estimates), we are likely accounting for the real variability and covering the representative $u$ and $C$ for each sampling period. However, these estimates only take into account those uncertainties associated with the different parameters, and do not consider those structural uncertainties related to the approach assumptions, which are difficult to accurately constrain.

The most critical assumption of the radon mass balance is that the empirical McIntyre equation (1995) provides accurate estimates of $k$ from measured wind speeds (as commonly done in the literature; e.g. Burnett and Dulaiova, 2003; Dimova and Burnett, 2011b). Recent studies have suggested that this equation 
might not be appropriate for shallow environments like coastal lagoons (Cockenpot et al., 2015). Had we used other empirical equations we would have obtained significantly different results, but most likely within the uncertainties of the current estimates: e.g. using an equation derived from Kremer et al. (2003) for shallow environments, we would have estimated recirculation-driven radon fluxes from $30 \%$ lower (in June 2016) to 60\% higher (in November 2016) than those obtained using the MacIntyre et al. (1995) gas-exchange equation.

Another critical assumption of the radon mass balance is assuming constant radon inventories during the 2-day period before surveys (i.e. $\frac{\partial C V_{N}}{\partial t}=0$ ). Radon concentrations might be highly variable over short temporal scales as a consequence of temporally variable wind-dependent radon evasion to the atmosphere, and thus dynamic modelling is often more appropriate than steady state mass balances (Dimova and Burnett, 2011b; Gilfedder et al., 2015; Stieglitz et al., 2013a). During a 1-month time series, Gilfedder et al. (2015) found that radon concentrations in surface water from a shallow (1-2 m) wetland could decrease up to $\sim 20 \%$ as consequence of wind speeds exceeding $5 \mathrm{~m} \mathrm{~s}^{-1}$. A daily decrease in radon concentrations by $\sim 20 \%$ in La Palme lagoon (i.e. $\frac{\partial C V_{N}}{\partial t}=-2 \cdot 10^{7}-8 \cdot 10^{7} \mathrm{~Bq} \mathrm{~d}^{-1}$, depending on the survey) would result on estimated radon fluxes from recirculation $10 \%$ - 40\% smaller than those estimated assuming constant radon inventories. Given that the surveys were conducted in periods with relatively constant wind conditions (for the 48 hours before sampling), we expect changes on radon concentrations and inventories over time not to be higher than the example above. 


\subsubsection{Uncertainties on estimating recirculation-driven water flows and net}

nutrient fluxes

In addition to the uncertainties associated with radon fluxes (section 6.1.1), the appropriate characterization of the radon concentration in the recirculation endmember is also a critical component of the final radon-derived water flow estimates (Cerdà-Domènech et al., 2017; Cook et al., 2018a, 2018b; Gonneea et al., 2013). Whereas it is clear that the radon concentration of porewater that should be used as recirculation endmember is the concentration immediately below the sediment-water interface, the depth at which a porewater concentration should be measured depends upon the hydrodynamic dispersivity (Cook et al., 2018a, 2018b). For solute transport on the order of $0.5-1 \mathrm{~m}$, Cook et al. (2018a) estimated that the endmember concentration should be measured within $1 \mathrm{~cm}$ of the sediment surface. Collecting porewaters at such shallow depths for radon analysis is virtually impossible. We acknowledge that by using radon concentrations from porewaters at $5 \mathrm{~cm}$ as endmembers rather than at $1 \mathrm{~cm}$ we are underestimating the water flow, and thus the flows provided here are conservative estimates.

Estimating the recirculation-driven nutrient flux also requires an accurate estimation of the excess ratio of nutrient over radon concentrations in the recirculation endmember. Whereas this approach also requires characterizing the ratio in discharging porewaters (i.e. within $1 \mathrm{~cm}$ below the sediment-water interface), the excess nutrient-radon concentration ratios of those nutrients produced in sediments (such as $\mathrm{NH}_{4}{ }^{+}$and $\mathrm{PO}_{4}^{3-}$; Fig. 8) vary significantly less with 
depth than absolute radon and nutrient concentrations do. Therefore, using the excess concentration ratios from the shallowest porewater sample (at $5 \mathrm{~cm}$ below the sediment-water interface) may provide a better constraint on the recirculation endmember, compared to absolute concentrations alone.

The estimation of recirculation water flows and net nutrient fluxes also relies on the assumption that the three piezometers used are representative of large specific sediment areas. This assumption alone can potentially introduce much larger uncertainties than those associated to parameter determination. Although the number of profiles is small, the relative similitude of radon concentrations and radon-nutrient ratios from the different profiles provides some level of confidence in the extrapolation.

\subsection{Nutrient fluxes to La Palme lagoon}

\subsubsection{Nutrient fluxes from karstic groundwater and lagoon water recirculation}

As commonly observed in other carbonate systems, groundwater-driven fluxes of dissolved inorganic nitrogen (DIN, mainly in the form of $\mathrm{NO}_{3}{ }^{-}$because highly oxic groundwater conditions limit denitrification) are significantly higher than those of dissolved inorganic phosphorous (DIP $=\mathrm{PO}_{4}{ }^{3-}$ ) (Table 3; Fig. 9). Whereas $\mathrm{P}$ is rapidly removed from groundwater through co-precipitation with dissolved Ca (Hernández-Terrones et al., 2011; Slomp and Van Cappellen, 2004; Weinstein et al., 2011), high DIN concentrations are commonly found in fast-flowing groundwater systems, such as karsts, mainly as a consequence of anthropogenic $\mathrm{N}$ inputs (e.g. 
fertilizers, manure, wastewater) and the lack of major removal processes (Slomp and Van Cappellen, 2004; Tovar-Sánchez et al., 2014; Weinstein et al., 2011).

Estimated nutrient fluxes from recirculation in La Palme lagoon reveal that sediments constitute a source of $\mathrm{NH}_{4}{ }^{+}$and $\mathrm{PO}_{4}{ }^{3-}$, and a sink of $\mathrm{NO}_{3}$ - (Table 3; Fig. 9). The cycling and transformation of nutrients in sediments is governed by several factors, such as the content of organic matter, dissolved oxygen, the type of sediments, as well as the processes and conditions in the overlying water column (Middelburg and Levin, 2009; Ni et al., 2017; Rigaud et al., 2013). Biogeochemical nutrient cycling in permeable sediments has been studied extensively (e.g. Anschutz et al., 2009; Devol, 2015; Huettel et al., 2014; Kroeger and Charette, 2008; Slomp and Van Cappellen, 2004). Mechanisms of $\mathrm{NO}_{3}{ }^{-}$ production/consumption in sediment largely depend on oxygen conditions, generally resulting in $\mathrm{NO}_{3}$ - production from sediments under oxic conditions due to nitrification and in $\mathrm{NO}_{3}{ }^{-}$consumption in sediments with low oxygen content, mainly due to denitrification or dissimilatory nitrate reduction to ammonium (DNRA) (Devol, 2015; Rigaud et al., 2013; Slomp and Van Cappellen, 2004). $\mathrm{NO}_{3}$ reduction processes and organic matter mineralization during early diagenesis, in particular under low oxygen conditions, result in the formation of various remineralization products, such as $\mathrm{NH}_{4}{ }^{+}$and, to a lesser extent, $\mathrm{PO}_{4}^{3-}$ (Devol, 2015; Middelburg and Levin, 2009; Rigaud et al., 2013). Whereas under slow diffusiondominated nutrient fluxes most of the produced $\mathrm{NH}_{4}+$ is nitrified in surface oxic sediments, rapid recirculation fluxes in permeable sediments (which allow for a continuous supply of $\mathrm{NO}_{3}{ }^{-}$and organic compounds from the water column) favor the release of $\mathrm{NH}_{4}{ }^{+}$from the sediment, bypassing the nitrification zone (Huettel et 
al., 2014; Kessler et al., 2012; Rao et al., 2008). Lagoon sediments can sequester and bury $\mathrm{PO}_{4}{ }^{3-}$ dissolved in lagoon waters, which can later be released to porewater mainly due to the aerobic and anaerobic mineralization of organic matter during early diagenesis (Anschutz et al., 2007; De Vittor et al., 2016; Mesnage and Picot, 1995). Thus, advective flushing of sediments under slightly oxic or anoxic conditions could explain recirculation-driven inputs of $\mathrm{NH}_{4}{ }^{+}$and $\mathrm{PO}_{4}{ }^{3-}$, as well as the removal of $\mathrm{NO}_{3}{ }^{-}$.

\subsubsection{Comparison of potential sources of nutrient to the lagoon}

To evaluate the significance of groundwater processes as conveyors of dissolved inorganic nutrients to La Palme lagoon, the estimated fluxes can be compared to the other potential sources of nutrients to the lagoon, including discharges from the sewage treatment plant, diffusion from sediments and atmospheric deposition.

Inputs of $\mathrm{NO}_{3}{ }^{-}, \mathrm{NH}_{4}{ }^{+}$and $\mathrm{PO}_{4}{ }^{3-}$ from the sewage treatment plant are on the order of $70 \pm 50,2.4 \pm 1.9$ and $12 \pm 7 \mathrm{~mol} \mathrm{~d}^{-1}$, respectively, as estimated from the water flows from the sewage treatment plant and the average nutrient concentrations measured in the effluent (Fig. 9). Inputs of nutrients from atmospheric deposition are derived from reported atmospheric DIN (120 - $\left.130 \mu \mathrm{mol} \mathrm{m}^{-2} \mathrm{~d}^{-1}\right)$ and DIP fluxes $\left(1.5-1.8 \mu \mathrm{mol} \mathrm{m}{ }^{-2} \mathrm{~d}^{-1}\right)$ in the nearby "Cap Bear" station $(\sim 50 \mathrm{~km}$ south of La

Palme lagoon) (Markaki et al., 2010), resulting in atmospheric fluxes of 550 - 580 mol d $\mathrm{d}^{-1}$ for DIN and $7-8 \mathrm{~mol} \mathrm{~d}^{-1}$ for DIP.

Diffusive fluxes of nutrients from sediments were calculated by applying Fick's first law (De Vittor et al., 2016). The specific diffusion coefficients of the evaluated 
nutrients were derived from (Schwarzenbach et al., 2002) and corrected for water temperature at each survey following (Li and Gregory, 1974). Diffusion fluxes were estimated using the measured nutrient gradients in shallow porewaters (from 0 to $5 \mathrm{~cm}$ below the sediment-water interface). Considering all the surveys and piezometers, estimated fluxes of nutrients driven by molecular diffusion from sediments are on the order of $3-5 \mathrm{~mol} \mathrm{~d}^{-1}$ for $\mathrm{NH}_{4}{ }^{+}$and $0.01-0.7 \mathrm{~mol} \mathrm{~d}^{-1}$ for $\mathrm{PO}_{4}{ }^{3-}$ (negative fluxes are obtained for $\mathrm{NO}_{3}$ - given the higher concentrations in overlying waters than in porewaters) (Fig. 9).

Despite the large uncertainties of these estimates, a comparison between all the potential nutrient sources (Fig. 9) reveals that karstic groundwater represents the main source of $\mathrm{NO}_{3}-$ to La Palme lagoon. Inputs of DIN from atmospheric deposition are likely comparable to karstic groundwater-driven fluxes of $\mathrm{NO}_{3}$ However, for $\mathrm{NH}_{4}{ }^{+}$and $\mathrm{PO}_{4}{ }^{3-}$, the recirculation of lagoon water through sediments is the most important nutrient source, accounting on average for $>80 \%$ and $>50 \%$ of total $\mathrm{NH}_{4}{ }^{+}$and $\mathrm{PO}_{4}{ }^{3-}$ inputs to La Palme lagoon, respectively. The estimated nutrient contribution from karstic groundwater and recirculation inputs is indeed in good agreement with the distribution of nutrients in lagoon waters of La Palme (Fig. 6): highest concentrations of $\mathrm{NO}_{3}^{-}$-were measured in low-salinity waters, indicating a low-salinity high- $\mathrm{NO}_{3}{ }^{-}$source (i.e. karstic groundwater discharge), and concentrations decreased with distance from this source. In contrast, concentrations of $\mathrm{NH}_{4}{ }^{+}$and $\mathrm{PO}_{4}{ }^{3-}$ did not show any clear pattern with salinity, with maximum concentrations found in mid-salinity waters located far from sewage and karstic groundwater inflows, which is consistent with inputs of $\mathrm{NH}_{4}{ }^{+}$and $\mathrm{PO}_{4}^{3-}$ from recirculation of lagoon water through sediments (Fig. 6). 


\subsection{The role of lagoon water recirculation as nutrient source}

Groundwater inputs from karstic springs represent the main source of freshwater to La Palme lagoon, contributing to maintain the lagoon under non-hypersaline conditions for most of the year and thus playing a relevant role for lagoon ecosystem functioning (Stieglitz et al., 2013a). Despite the volumetric importance of karstic groundwater inputs to La Palme lagoon, nutrient fluxes estimated in this work indicate that the recirculation of lagoon water through sediments is likely the main source of both dissolved inorganic nitrogen (DIN) and phosphorous (DIP) to La Palme lagoon. These results are in contrast with most of the studies conducted in systems influenced by fresh groundwater inputs that have attempted to differentiate nutrient fluxes from terrestrial groundwater and recirculation flows. In the only other study conducted in the Mediterranean Sea, Weinstein et al. (2011) found that the nutrient loads regenerated in coastal sediments during seawater recirculation were relatively low, resulting in nutrient-poor recirculated seawater inputs, whereas terrestrial, fresh groundwater was the main source of nutrients. Other studies, most of them conducted in the Atlantic shoreline of the USA, suggested that recirculated saline water might deliver significant loads of nutrients, although the nitrogen fluxes from terrestrial groundwater discharge were significantly higher (e.g. Bernard et al., 2014; Kroeger and Charette, 2008; Santos et al., 2009) or comparable (e.g. Kroeger et al., 2007; Sadat-Noori et al., 2016; Tamborski et al., 2017) than those supplied by saline water recirculation.

Unlike most of the previous sites where groundwater inputs occur via diffusive (non-point source) discharge processes, groundwater discharge in La Palme 
lagoon is via point-sourced, karstic springs. The influence of karstic groundwater inputs is thus restricted to areas close to the springs. In contrast, recirculation fluxes are essentially ubiquitous in areas with permeable sediments. Therefore, the relative significance of recirculation fluxes as a source of nutrients may be even higher for most of the areas not influenced by karstic groundwater inputs. The important role of recirculation fluxes in La Palme lagoon is also partially enhanced by the shallow water column of the site $(<2 \mathrm{~m})$, which may favor the recirculation of water through sediments (e.g. the interaction between wave-driven oscillatory flows and seabed morphology increases in shallow waters; Precht and Huettel, 2003) and the accumulation of compounds in lagoon waters. The relative importance of recirculation-driven nutrient inputs might thus be particularly relevant in shallow systems covered by permeable sediments.

Solute inputs from lagoon water recirculation may have a critical impact on the primary production of this system. Fluxes of nutrients to La Palme lagoon from karstic groundwater discharge and water recirculation have DIN/DIP ratios above the Redfield ratio (DIN/DIP of 140-500 in the karstic spring and 30-230 in recirculation fluxes). Surfaces waters from most of the lagoon appear to be Nlimited (DIN/DIP < 10), with the exception of fresher areas highly influenced by karstic groundwater inputs, which are P-limited. Therefore, recirculation-driven nutrient fluxes may represent a relevant source of dissolved inorganic nitrogen to support phytoplankton growth in areas not influenced by karstic inputs. Nitrogen inputs from recirculation of lagoon waters through sediments are largely supplied in the form of $\mathrm{NH}_{4}{ }^{+}$, whose uptake by primary producers is preferred over $\mathrm{NO}_{3}{ }^{-}$ uptake due to reduced energetic costs associated with its utilization (Cohen and 
Fong, 2005; Jauzein et al., 2017; Middelburg and Nieuwenhuize, 2000). Nutrient inputs supplied by lagoon water recirculation are thus expected to play a relevant role in the ecological functioning of the lagoon.

It is beyond the scope of this paper to evaluate the physical or biological mechanisms driving the recirculation of these large amounts of lagoon water through sediments. A number of different mechanisms have been identified to force flow across the sediment-water interface, including wave and tidal pumping, interaction of bottom currents and seafloor topography, density instabilities or pumping activities of benthic fauna (Huettel et al., 2014; Santos et al., 2012). In the case of La Palme lagoon, Stieglitz et al (2013a) suggested that wind-driven variations of lagoon water levels could represent the main mechanism inducing recirculation flows. More recently, Cook et al (2018a) indicated that the shape of radon porewater depth profiles in La Palme lagoon is consistent with porewater exchange driven by pressure gradients reversing at short temporal scales, such as those produced by the action of wind-driven waves. Other studies in lagoonal embayments have also suggested that the burrowing activities of benthic fauna (bioturbation and bioirrigation) can drive the exchange of significant amounts of water between sediments and overlying water, in similar magnitudes than those observed in La Palme lagoon (0.01-0.03 $\mathrm{m}^{3} \mathrm{~m}^{-2} \mathrm{~d}^{-1}$ ) (Martin et al., 2006; Rodellas et al., 2017; Roskosch et al., 2012; Stieglitz et al., 2013b).

\section{CONCLUSIONS}

The significant contribution of recirculated lagoon waters to the studied lagoon highlights the importance of this often-overlooked process as a conveyor of 
dissolved inorganic nutrients to coastal and lagoonal ecosystems. These findings emphasize the need for a sound understanding of these recirculation-driven nutrient fluxes and their ecological implications to properly understand the functioning and vulnerability of coastal lagoonal ecosystems. Future studies on the nutrient biogeochemical cycling in coastal lagoons, as well as management strategies towards the mitigation of the negative impacts of eutrophication in these ecosystems, should thus properly evaluate the loads of nutrients and other solutes supplied by lagoon water recirculation through sediments.

\section{Acknowledgements}

This research is a contribution to the ANR @RAction chair (ANR-14-ACHN-000701) and Labex OT-Med (ANR-11-LABEX-0061, part of the "Investissements d'Avenir" program through the A*MIDEX project ANR-11-IDEX-0001-02) funded by the French National Research Agency (ANR). This project has received funding from the European Union's Horizon 2020 research and innovation programme under the Marie Skłodowska-Curie grant agreement No 748896. PC acknowledges support from IméRA (Institute of Advanced Studies), Aix-Marseille Université (Labex RFIEA and ANR “Investissements d'avenir”). JT fellowship is supported by the SELECT project funded by the European Union and Région Occitanie (FEDER). We thank C Fleger and K Fortune from the "Parc Naturel Régional de la Narbonnaise en Méditerranée" (PNRNM), J Garcia-Orellana and JM Bruach (UAB, Barcelona) for radon measurements via liquid scintillation counting, R Marchant (CEREGE, Aix-en-Provence) for the treatment and processing of Marotte HS data and N Garcia (MIO, Marseille) for the help in nutrient analysis. We are also grateful 
to S Meulé and the GLADYS research group (www.gladys-littoral.org) who supported the experimentation.

\section{REFERENCES}

Adyasari, D., Oehler, T., Afiati, N., Moosdorf, N., 2018. Groundwater nutrient inputs inot an urbanized tropical estuary system in Indonesia. Sci. Total Environ. 627, 1066-1079.

Aminot, A., Kérouel, R., 2007. Dosage automatique des nutriments dans les eaux marines: méthodes en flux continu. Editions IFREMER.

Anschutz, P., Chaillou, G., Lecroart, P., 2007. Phosphorus diagenesis in sediment of the Thau Lagoon. Estuar. Coast. Shelf Sci. 72, 447-456. doi:10.1016/J.ECSS.2006.11.012

Anschutz, P., Smith, T., Mouret, A., Deborde, J., Bujan, S., Poirier, D., Lecroart, P., 2009. Tidal sands as biogeochemical reactors. Estuar. Coast. Shelf Sci. 84, 8490. doi:10.1016/j.ecss.2009.06.015

Beer, N.A., Joyce, C.B., 2013. North Atlantic coastal lagoons: conservation, management and research challenges in the twenty-first century. Hydrobiologia 701, 1-11. doi:10.1007/s10750-012-1325-4

Bejannin, S., van Beek, P., Stieglitz, T., Souhaut, M., Tamborski, J., 2017. Combining airborne thermal infrared images and radium isotopes to study submarine groundwater discharge along the French Mediterranean coastline. J. Hydrol. Reg. Stud. 13, 72-90. doi:10.1016/J.EJRH.2017.08.001

Bernard, R., Mortazavi, B., Wang, L., Ortmann, A., MacIntyre, H., Burnett, W., 2014. Benthic nutrient fluxes and limited denitrification in a sub-tropical groundwater-influenced coastal lagoon. Mar. Ecol. Prog. Ser. 504, 13-26. doi:10.3354/meps10783

Beusen, A., Slomp, C.P., Bouwman, A.F., 2013. Global land-ocean linkage: direct inputs of nitrogen to coastal waters via submarine groundwater discharge. Environtal Res. Lett. 8, 34035.

Brito, A.C., Newton, A., Tett, P., Fernandes, T.F., 2012. How will shallow coastal lagoons respond to climate change? A modelling investigation. Estuar. Coast. 
Shelf Sci. 112, 98-104. doi:10.1016/J.ECSS.2011.09.002

Burnett, W.C., Dulaiova, H., 2003. Estimating the dynamics of groundwater input

into the coastal zone via continuous radon-222 measurements. J. Environ.

Radioact. 69, 21-35. doi:10.1016/S0265-931X(03)00084-5

Burnett, W.C., Aggarwal, P.K., Aureli, A., Bokuniewicz, H., Cable, J.E., Charette, M.A., Kontar, E., Krupa, S., Kulkarni, K.M., Loveless, A., Moore, W.S., Oberdorfer, J.A., Oliveira, J., Ozyurt, N., Povinec, P., Privitera, A.M.G., Rajar, R., Ramessur, R.T., Scholten, J., Stieglitz, T., Taniguchi, M., Turner, J. V, 2006. Quantifying submarine groundwater discharge in the coastal zone via multiple methods. Sci. Total Environ. 367, 498-543. doi:10.1016/j.scitotenv.2006.05.009

Cable, J.E., Martin, J.B., 2008. In situ evaluation of nearshore marine and fresh pore water transport into Flamengo Bay, Brazil. Estuar. Coast. Shelf Sci. 76, 473483. doi:10.1016/j.ecss.2007.07.045

Capone, D.G., 2008. Nitrogen in the marine environment. Elsevier.

Cerdà-Domènech, M., Rodellas, V., Folch, A., Garcia-Orellana, J., 2017. Constraining the temporal variations of Ra isotopes and $\mathrm{Rn}$ in the groundwater endmember: Implications for derived SGD estimates. Sci. Total Environ. 595, 849857. doi:10.1016/j.scitotenv.2017.03.005

Charette, M.A., Allen, M.C., 2006. Precision Ground Water Sampling in Coastal Aquifers Using a Direct-Push, Shielded-Screen Well-Point System. Gr. Water Monit. Remediat. 26, 87-93. doi:10.1111/j.1745-6592.2006.00076.x

Charette, M.A., Buesseler, K.O., 2004. Submarine groundwater discharge of nutrients and copper to an urban subestuary of Chesapeake Bay (Elizabeth River). Limnol. Oceanogr. 49, 376-385.

Christensen, P., Rysgaard, S., Sloth, N., Dalsgaard, T., Schwærter, S., 2000. Sediment mineralization, nutrient fluxes, denitrification and dissimilatory nitrate reduction to ammonium in an estuarine fjord with sea cage trout farms. Aquat. Microb. Ecol. 21, 73-84. doi:10.3354/ame021073

Cloern, J.E., 2001. Our evolving conceptual model of the coastal eutrophication problem. Mar. Ecol. Prog. Ser. 210, 223-253. doi:10.2307/24863878

Cockenpot, S., Claude, C., Radakovitch, O., 2015. Estimation of air-water gas exchange coefficient in a shallow lagoon based on (222)Rn mass balance. J. Environ. Radioact. 143, 58-69. doi:10.1016/j.jenvrad.2015.02.007 
Cohen, R.A., Fong, P., 2005. Experimental evidence supports the use of $\delta 15 \mathrm{~N}$ content of the opportunistic green macro alga Enteromorpha intestinalis (Chlorophyta) to determine nitrogen sources to estuaries. J. Phycol. 41, 287293. doi:10.1111/j.1529-8817.2005.04022.x

Cook, P.G., Lamontagne, S., Berhane, D., Clark, J.F., 2006. Quantifying groundwater discharge to Cockburn River, southeastern Australia, using dissolved gas tracers 222 Rn and SF 6. Water Resour. Res. 42. doi:10.1029/2006WR004921

Cook, P.G., Wood, C., White, T., Simmons, C.T., Fass, T., Brunner, P., 2008.

Groundwater inflow to a shallow, poorly-mixed wetland estimated from a mass balance of radon. J. Hydrol. 354, 213-226. doi:10.1016/j.jhydrol.2008.03.016

Cook, P.G., Rodellas, V., Andrisoa, A., Stieglitz, T.C., 2018a. Exchange across the sediment-water interface quantified from porewater radon profiles. J. Hydrol. 559, 873-883. doi:10.1016/j.jhydrol.2018.02.070

Cook, P.G., Rodellas, V., Stieglitz, T.C., 2018b. Quantifying Surface Water, Porewater and Groundwater Interactions Using Tracers: Tracer Fluxes, Water Fluxes and Endmember Concentrations. Water Resour. Res. doi:10.1002/2017WR021780

Corbett, D.R., Burnett, W.C., Cable, P.H., Clark, S.B., 1998. A multiple approach to the determination of radon fluxes from sediments. J. Radioanal. Nucl. Chem. 236, 247-253. doi:10.1007/BF02386351

de Jonge, V.N., Elliott, M., Orive, E., 2002. Causes, historical development, effects and future challenges of a common environmental problem: eutrophication, in: Nutrients and Eutrophication in Estuaries and Coastal Waters. Springer Netherlands, Dordrecht, pp. 1-19. doi:10.1007/978-94-017-2464-7_1

De Vittor, C., Relitti, F., Kralj, M., Covelli, S., Emili, A., 2016. Oxygen, carbon, and nutrient exchanges at the sediment-water interface in the Mar Piccolo of Taranto (Ionian Sea, southern Italy). Environ. Sci. Pollut. Res. 23, 1256612581. doi:10.1007/s11356-015-4999-0

Devol, A.H., 2015. Denitrification, Anammox, and $\mathrm{N}_{2}$ Production in Marine Sediments. Ann. Rev. Mar. Sci. 7, 403-423. doi:10.1146/annurev-marine010213-135040

Dimova, N.T., Burnett, W.C., 2011a. Evaluation of groundwater discharge into small 
lakes based on the temporal distribution of radon-222. Limnol. Oceanogr. 56, 486-494. doi:10.4319/lo.2011.56.2.0486

Dimova, N.T., Burnett, W.C., 2011b. Evaluation of groundwater discharge into small lakes based on the temporal distribution of radon-222. Limnol. Oceanogr. 56, 486-494. doi:10.4319/lo.2011.56.2.0486

Dulaiova, H., Peterson, R., Burnett, W.C., Lane-Smith, D., 2005. A multi-detector continuous monitor for assessment of $222 \mathrm{Rn}$ in the coastal ocean. J. Radioanal. Nucl. Chem. 263, 361-363. doi:10.1007/s10967-005-0063-8

Fiandrino, A., Giraud, A., Robin, S., Pinatel, C., 2012. Validation d'une méthode d'estimation des volumes d'eau échangés entre la mer et les lagunes et définition d'indicateurs hydrodynamiques associés.

Garcés, E., Basterretxea, G., Tovar-Sánchez, A., 2011. Changes in microbial communities in response to submarine groundwater input. Mar. Ecol. Prog. Ser. 438, 47-58. doi:10.3354/meps09311

Garcia-Solsona, E., Garcia-Orellana, J., Masqué, P., Rodellas, V., Mejías, M., Ballesteros, B., Domínguez, J.A., 2010. Groundwater and nutrient discharge through karstic coastal springs (Castelló, Spain). Biogeosciences 7, 26252638. doi:10.5194/bg-7-2625-2010

Gilfedder, B.S., Frei, S., Hofmann, H., Cartwright, I., 2015. Groundwater discharge to wetlands driven by storm and flood events: Quantification using continuous Radon-222 and electrical conductivity measurements and dynamic massbalance modelling. Geochim. Cosmochim. Acta 165, 161-177. doi:10.1016/J.GCA.2015.05.037

Gobler, C., Sañudo-Wilhelmy, S., 2001. Temporal variability of groundwater seepage and brown tide blooms in a Long Island embayment. Mar. Ecol. Prog. Ser. 217, 299-309.

Gonneea, M.E., Mulligan, A.E., Charette, M.A., 2013. Seasonal cycles in radium and barium within a subterranean estuary: Implications for groundwater derived chemical fluxes to surface waters. Geochim. Cosmochim. Acta 119, 164-177. doi:10.1016/j.gca.2013.05.034

Hernández-Terrones, L., Rebolledo-Vieyra, M., Merino-Ibarra, M., Soto, M., LeCossec, A., Monroy-Ríos, E., 2011. Groundwater Pollution in a Karstic Region (NE Yucatan): Baseline Nutrient Content and Flux to Coastal Ecosystems. 
Water, Air, Soil Pollut. 218, 517-528. doi:10.1007/s11270-010-0664-x

Holliday, D., Stieglitz, T., Ridd, P., Read, W., 2007. Geological controls and tidal forcing of submarine groundwater discharge from a confined aquifer in a coastal sand dune system. J. Geophys. Res. Ocean. 112.

doi:10.1029/2006JC003580

Holmes, R.M., Aminot, A., Kérouel, R., Hooker, B.A., Peterson, B.J., 1999. A simple and precise method for measuring ammonium in marine and freshwater ecosystems. Can. J. Fish. Aquat. Sci. 56, 1801-1808. doi:10.1139/f99-128

Howarth, R., Chan, F., Conley, D.J., Garnier, J., Doney, S.C., Marino, R., Billen, G., 2011. Coupled biogeochemical cycles: eutrophication and hypoxia in temperate estuaries and coastal marine ecosystems. Front. Ecol. Environ. 9, 18-26. doi:10.1890/100008

Huettel, M., Berg, P., Kostka, J.E., 2014. Benthic exchange and biogeochemical cycling in permeable sediments. Ann. Rev. Mar. Sci. 6, 23-51. doi:10.1146/annurev-marine-051413-012706

IFREMER, 2003. Réseau de Suivi Lagunaire du Languedoc-Roussillon: 4 - Etang de La Palme. Sète, France.

IFREMER, 2010. Construction d'un outil permettant d'estimer les charges en azote et phosphore admissibles en milieu lagunaire.

Jauzein, C., Couet, D., Blasco, T., Lemée, R., 2017. Uptake of dissolved inorganic and organic nitrogen by the benthic toxic dinoflagellate Ostreopsis cf. ovata. Harmful Algae 65, 9-18. doi:10.1016/J.HAL.2017.04.005

Jennerjahn, T.C., Mitchell, S.B., 2013. Pressures, stresses, shocks and trends in estuarine ecosystems - An introduction and synthesis. Estuar. Coast. Shelf Sci. 130, 1-8. doi:10.1016/J.ECSS.2013.07.008

Ji, T., Du, J., Moore, W.S., Zhang, G., Su, N., Zhang, J., 2013. Nutrient inputs to a Lagoon through submarine groundwater discharge: The case of Laoye Lagoon, Hainan, China. J. Mar. Syst. 111-112, 253-262. doi:10.1016/j.jmarsys.2012.11.007

Kessler, A.J., Glud, R.N., Cardenas, M.B., Larsen, M., Bourke, M.F., Cook, P.L.M., 2012. Quantifying denitrification in rippled permeable sands through combined flume experiments and modeling. Limnol. Oceanogr. 57, 1217-1232. doi:10.4319/lo.2012.57.4.1217 
Kirkwood, D.., 1992. Stability of solutions of nutrient salts during storage. Mar. Chem. 38, 151-164. doi:10.1016/0304-4203(92)90032-6

Kjerfve, B., 1994. Coastal lagoon processes. Elsevier.

Knee, K.L., Paytan, A., 2011. Submarine Groundwater Discharge: A Source of Nutrients, Metals, and Pollutants to the Coastal Ocean, in: Wolanski, E., McLusky, D. (Eds.), Treatise on Estuarine and Coastal Science. Elsevier, pp. 205-233. doi:10.1016/B978-0-12-374711-2.00410-1

Kremer, J.N., Reischauer, A., D’Avanzo, C., 2003. Estuary-specific variation in the air-water gas exchange coefficient for oxygen. Estuaries 26, 829-836. doi:10.1007/BF02803341

Kroeger, K.D., Charette, M.A., 2008. Nitrogen biogeochemistry of submarine groundwater discharge. Limnol. Oceanogr. 53, 1025-1039.

Kroeger, K.D., Greenwood, W.J., Reich, C., 2007. Submarine groundwater discharge to Tampa Bay: Nutrient fluxes and biogeochemistry of the coastal aquifer. Mar. Chem. 104, 85-97. doi:10.1016/J.MARCHEM.2006.10.012

Lee, Y.-W., Kim, G., 2007. Linking groundwater-borne nutrients and dinoflagellate red-tide outbreaks in the southern sea of Korea using a Ra tracer. Estuar. Coast. Shelf Sci. 71, 309-317. doi:10.1016/j.ecss.2006.08.004

Li, Y.-H., Gregory, S., 1974. Diffusion of ions in sea water and in deep-sea sediments. Geochim. Cosmochim. Acta 38, 703-714. doi:10.1016/00167037(74)90145-8

Liu, Q., Dai, M., Chen, W., Huh, C.-A., Wang, G., Li, Q., Charette, M.A., 2012. How significant is submarine groundwater discharge and its associated dissolved inorganic carbon in a river-dominated shelf system? Biogeosciences 9, 17771795. doi:10.5194/bg-9-1777-2012

Lloret, J., Marín, A., Marín-Guirao, L., 2008. Is coastal lagoon eutrophication likely to be aggravated by global climate change? Estuar. Coast. Shelf Sci. 78, 403412. doi:10.1016/j.ecss.2008.01.003

MacIntyre, S., Wanninkhof, R., Chanton, J.P., 1995. Trace gas exchange across the air-water interface in freshwater and coastal marine environments, in: Matson, P.A., Harris, R.C. (Eds.), Biogenic Trace Gases: Measuring Emissions from Soil and Water. Blackwell Science Ltd, Cambridge, MA, pp. 52-97.

Malta, E., Stigter, T.Y., Pacheco, A., Dill, A.C., Tavares, D., Santos, R., 2017. Effects of 
External Nutrient Sources and Extreme Weather Events on the Nutrient Budget of a Southern European Coastal Lagoon. Estuaries and Coasts 40, 419436. doi:10.1007/s12237-016-0150-9

Markaki, Z., Loÿe-Pilot, M.D., Violaki, K., Benyahya, L., Mihalopoulos, N., 2010. Variability of atmospheric deposition of dissolved nitrogen and phosphorus in the Mediterranean and possible link to the anomalous seawater N/P ratio. Mar. Chem. 120, 187-194. doi:10.1016/j.marchem.2008.10.005

Martens, C.S., Kipphut, G.W., Klump, J. V., 1980. Sediment-Water Chemical Exchange in the Coastal Zone Traced by in situ Radon-222 Flux Measurements. Science (80-. ). 208, 285-288. doi:10.1126/science.208.4441.285

Martin, J.B., Cable, J.E., Jaeger, J., Hartl, K., Smith, C.G., 2006. Thermal and chemical evidence for rapid water exchange across the sediment-water interface by bioirrigation in the Indian River Lagoon, Florida. Limnol. Oceanogr. 51, 13321341. doi:10.4319/lo.2006.51.3.1332

Martínez-Soto, M.C., Tovar-Sánchez, A., Sánchez-Quiles, D., Rodellas, V., GarciaOrellana, J., Basterretxea, G., 2016. Seasonal variation and sources of dissolved trace metals in Maó Harbour, Minorca Island. Sci. Total Environ. 565. doi:10.1016/j.scitotenv.2016.03.244

Mesnage, V., Picot, B., 1995. The distribution of phosphate in sediments and its relation with eutrophication of a Mediterranean coastal lagoon. Hydrobiologia 297, 29-41. doi:10.1007/BF00033499

Middelburg, J.J., Nieuwenhuize, J., 2000. Uptake of dissolved inorganic nitrogen in turbid, tidal estuaries. Mar. Ecol. Prog. Ser. doi:10.2307/24855713

Middelburg, J.J., Levin, L.A., 2009. Coastal hypoxia and sediment biogeochemistry. Biogeosciences 6, 1273-1293. doi:10.5194/bg-6-1273-2009

Moore, W.S., 1999. The subterranean estuary: a reaction zone of ground water and sea water. Mar. Chem. 65, 111-125. doi:10.1016/S0304-4203(99)00014-6

Moore, W.S., 2010. The Effect of Submarine Groundwater Discharge on the Ocean. Ann. Rev. Mar. Sci. 2, 59-88. doi:10.1146/annurev-marine-120308-081019

Moore, W.S., Reid, D.F., 1973. Extraction of radium from natural waters using manganese-impregnated acrylic fibers. J. Geophys. Res. 78, 8880-8886. doi:10.1029/JC078i036p08880 
Newton, A., Icely, J., Cristina, S., Brito, A., Cardoso, A.C., Colijn, F., Riva, S.D., Gertz, F., Hansen, J.W., Holmer, M., Ivanova, K., Leppäkoski, E., Canu, D.M., Mocenni, C., Mudge, S., Murray, N., Pejrup, M., Razinkovas, A., Reizopoulou, S., PérezRuzafa, A., Schernewski, G., Schubert, H., Carr, L., Solidoro, C., PierluigiViaroli, Zaldívar, J.-M., 2014. An overview of ecological status, vulnerability and future perspectives of European large shallow, semi-enclosed coastal systems, lagoons and transitional waters. Estuar. Coast. Shelf Sci. 140, 95-122. doi:10.1016/J.ECSS.2013.05.023

Ni, Z., Zhang, L., Yu, S., Jiang, Z., Zhang, J., Wu, Y., Zhao, C., Liu, S., Zhou, C., Huang, X., 2017. The porewater nutrient and heavy metal characteristics in sediment cores and their benthic fluxes in Daya Bay, South China. Mar. Pollut. Bull. 124, 547-554. doi:10.1016/J.MARPOLBUL.2017.07.069

Peng, T.-H., Takahashi, T., Broecker, W.S., 1974. Surface radon measurements in the North Pacific Ocean station Papa. J. Geophys. Res. 79, 1772-1780. doi:10.1029/JC079i012p01772

Penman, H.L., 1948. Natural evaporation from open water, hare soil and grass. Proc. R. Soc. Lond. A. Math. Phys. Sci. 193, 120-45. doi:10.1098/RSPA.1948.0037

Precht, E., Huettel, M., 2003. Advective pore-water exchange driven by surface gravity waves and its ecological implications. Limnol. Oceanogr. 48, 16741684. doi:10.4319/lo.2003.48.4.1674

Raimbault, P., Slawyk, G., Coste, B., Fry, J., 1990. Feasibility of using an automated colorimetric procedure for the determination of seawater nitrate in the 0 to 100 nM range: Examples from field and culture. Mar. Biol. 104, 347-351. doi:10.1007/BF01313277

Rao, A.M.F., McCarthy, M.J., Gardner, W.S., Jahnke, R.A., 2008. Respiration and denitrification in permeable continental shelf deposits on the South Atlantic Bight: N2:Ar and isotope pairing measurements in sediment column experiments. Cont. Shelf Res. 28, 602-613. doi:10.1016/J.CSR.2007.11.007

Rigaud, S., Radakovitch, O., Couture, R.M., Deflandre, B., Cossa, D., Garnier, C., Garnier, J.M., 2013. Mobility and fluxes of trace elements and nutrients at the sediment-water interface of a lagoon under contrasting water column oxygenation conditions. Appl. Geochemistry 31, 35-51. 
doi:10.1016/J.APGEOCHEM.2012.12.003

Rodellas, V., Garcia-Orellana, J., Garcia-Solsona, E., Masqué, P., Domínguez, J.A., Ballesteros, B.J., Mejías, M., Zarroca, M., 2012. Quantifying groundwater discharge from different sources into a Mediterranean wetland by using 222Rn and Ra isotopes. J. Hydrol. 466-467, 11-22. doi:10.1016/j.jhydrol.2012.07.005

Rodellas, V., Garcia-Orellana, J., Masqué, P., Feldman, M., Weinstein, Y., Boyle, E.A., 2015. Submarine groundwater discharge as a major source of nutrients to the Mediterranean Sea. Proc. Natl. Acad. Sci. U. S. A. 112. doi:10.1073/pnas.1419049112

Rodellas, V., Garcia-Orellana, J., Trezzi, G., Masqué, P., Stieglitz, T.C., Bokuniewicz, H., Cochran, J.K., Berdalet, E., 2017. Using the radium quartet to quantify submarine groundwater discharge and porewater exchange. Geochim. Cosmochim. Acta 196. doi:10.1016/j.gca.2016.09.016

Roskosch, A., Hette, N., Hupfer, M., Lewandowski, J., 2012. Alteration of Chironomus plumosus ventilation activity and bioirrigation-mediated benthic fluxes by changes in temperature, oxygen concentration, and seasonal variations. Freshw. Sci. 31, 269-281. doi:10.1899/11-043.1

Sadat-Noori, M., Santos, I.R., Tait, D.R., Maher, D.T., 2016. Fresh meteoric versus recirculated saline groundwater nutrient inputs into a subtropical estuary. Sci. Total Environ. 566-567, 1440-1453. doi:10.1016/J.SCITOTENV.2016.06.008 Santos, I.R., Burnett, W.C., Chanton, J., Mwashote, B., Suryaputra, I.G.N.A., Dittmar, T., 2008. Nutrient biogeochemistry in a Gulf of Mexico subterranean estuary and groundwater-derived fluxes to the coastal ocean. Limnol. Oceanogr. 53, 705-718.

Santos, I.R., Burnett, W.C., Dittmar, T., Suryaputra, I.G.N.A., Chanton, J., 2009. Tidal pumping drives nutrient and dissolved organic matter dynamics in a Gulf of Mexico subterranean estuary. Geochim. Cosmochim. Acta 73, 1325-1339. doi:10.1016/j.gca.2008.11.029

Santos, I.R., Eyre, B.D., Huettel, M., 2012. The driving forces of porewater and groundwater flow in permeable coastal sediments: A review. Estuar. Coast. Shelf Sci. 98, 1-15. doi:10.1016/j.ecss.2011.10.024

Schubert, M., Paschke, A., Bednorz, D., Bürkin, W., Stieglitz, T., 2012a. Kinetics of 
the Water/Air Phase Transition of Radon and Its Implication on Detection of Radon-in-Water Concentrations: Practical Assessment of Different On-Site Radon Extraction Methods. Environ. Sci. Technol. 46, 8945-8951. doi:10.1021/es3019463

Schubert, M., Paschke, A., Lieberman, E., Burnett, W.C., 2012b. Air-water partitioning of 222Rn and its dependence on water temperature and salinity. Environ. Sci. Technol. 46, 3905-11. doi:10.1021/es204680n

Schwarzenbach, R.P., Gschwend, P.M., Imboden, D.M., 2002. Environmental Organic Chemistry. John Wiley \& Sons, Inc., Hoboken, NJ, USA. doi:10.1002/0471649643

Slomp, C.P., Van Cappellen, P., 2004. Nutrient inputs to the coastal ocean through submarine groundwater discharge: controls and potential impact. J. Hydrol. 295, 64-86. doi:10.1016/j.jhydrol.2004.02.018

Smith, C.G., Cable, J.E., Martin, J.B., Roy, M., 2008. Evaluating the source and seasonality of submarine groundwater discharge using a radon-222 pore water transport model. Earth Planet. Sci. Lett. 273, 312-322. doi:10.1016/j.epsl.2008.06.043

Stieglitz, T.C., Cook, P.G., Burnett, W.C., 2010. Inferring coastal processes from regional-scale mapping of 222Radon and salinity: examples from the Great Barrier Reef, Australia. J. Environ. Radioact. 101, 544-52. doi:10.1016/j.jenvrad.2009.11.012

Stieglitz, T.C., Beek, P., Souhaut, M., Cook, P.G., 2013a. Karstic groundwater discharge and seawater recirculation through sediments in shallow coastal Mediterranean lagoons, determined from water, salt and radon budgets. Mar. Chem. 156, 73-84. doi:10.1016/j.marchem.2013.05.005

Stieglitz, T.C., Clark, J.F., Hancock, G.J., 2013b. The mangrove pump: The tidal flushing of animal burrows in a tropical mangrove forest determined from radionuclide budgets. Geochim. Cosmochim. Acta 102, 12-22. doi:10.1016/j.gca.2012.10.033

Szymczycha, B., Vogler, S., Pempkowiak, J., 2012. Nutrient fluxes via submarine groundwater discharge to the Bay of Puck, southern Baltic Sea. Sci. Total Environ. 438, 86-93. doi:10.1016/J.SCITOTENV.2012.08.058

Tait, D.R., Erler, D. V., Santos, I.R., Cyronak, T.J., Morgenstern, U., Eyre, B.D., 2014. 
The influence of groundwater inputs and age on nutrient dynamics in a coral reef lagoon. Mar. Chem. 166, 36-47. doi:10.1016/J.MARCHEM.2014.08.004

Tamborski, J.J., Cochran, J.K., Bokuniewicz, H.J., 2017. Submarine groundwater discharge driven nitrogen fluxes to Long Island Sound, NY: Terrestrial vs. marine sources. Geochim. Cosmochim. Acta 218, 40-57. doi:10.1016/J.GCA.2017.09.003

Tovar-Sánchez, A., Basterretxea, G., Rodellas, V., Sánchez-Quiles, D., GarcíaOrellana, J., Masqué, P., Jordi, A., López, J.M., Garcia-Solsona, E., 2014. Contribution of groundwater discharge to the coastal dissolved nutrients and trace metal concentrations in Majorca Island: Karstic vs detrital systems. Environ. Sci. Technol. 48. doi:10.1021/es502958t

Trezzi, G., Garcia-Orellana, J., Santos-Echeandia, J., Rodellas, V., Garcia-Solsona, E., Garcia-Fernandez, G., Masqué, P., 2016. The influence of a metal-enriched mining waste deposit on submarine groundwater discharge to the coastal sea. Mar. Chem. 178, 35-45. doi:10.1016/j.marchem.2015.12.004

Ullman, W.J., Aller, R.C., 1982. Diffusion coefficients in nearshore marine sediments1. Limnol. Oceanogr. 27, 552-556. doi:10.4319/lo.1982.27.3.0552 Valiela, I., Foreman, K., LaMontagne, M., Hersh, D., Costa, J., Peckol, P., DeMeoAndreson, B., D’Avanzo, C., Babione, M., Sham, C.-H., Brawley, J., Lajtha, K., 1992. Couplings of Watersheds and Coastal Waters: Sources and Consequences of Nutrient Enrichment in Waquoit Bay, Massachusetts. Estuaries 15, 443. doi:10.2307/1352389

Wanninkhof, R., 2014. Relationship between wind speed and gas exchange over the ocean revisited. Limnol. Oceanogr. Methods 12, 351-362. doi:10.4319/lom.2014.12.351

Weinstein, Y., Yechieli, Y., Shalem, Y., Burnett, W.C., Swarzenski, P.W., Herut, B., 2011. What is the role of fresh groundwater and recirculated seawater in conveying nutrients to the coastal ocean? Environ. Sci. Technol. 45, 5195-200. doi:10.1021/es104394r

Wilke, M., Boutière, H., 2000. Synthèse générale du fonctionnement hydrobiologique de l'étang de La Palme, CEH. Perpignan, France.

Windom, H.L., Moore, W.S., Niencheski, L.F.H., Jahnke, R.A., 2006. Submarine groundwater discharge: A large, previously unrecognized source of dissolved 
iron to the South Atlantic Ocean. Mar. Chem. 102, 252-266.

doi:10.1016/j.marchem.2006.06.016 


\section{LIST OF FIGURES}

Figure 1. Study site (La Palme lagoon) location on the French Mediterranean coastline. Sampling locations for endmembers (karstic spring, sewage effluent and seawater) and porewaters (piezometer) are shown, as well as the position of monitoring stations from the "Parc Naturel Régional de la Narbonaisse en Méditerranée" (PN station) and the site where the current meter was installed (CM).

Figure 2. Precipitation, surface water level and salinity in La Palme lagoon during 2016 and 2017 (Precipitation data from "Météo France"; surface water depth and salinity data from the three monitoring stations of PNRNM, see Fig. 1). Periods of the surveys are indicated by vertical gray lines.

Figure 3. Depth profiles (in cm below the sediment-water interface) of salinity and radon concentration in porewater for the three piezometers collected at each campaign. Reported values at a depth of 0 corresponds to the samples collected in surface waters ( $\sim 10 \mathrm{~cm}$ above the sediment-water interface). The gray area represents radon concentration in equilibrium with sediments estimated from equilibration experiments.

Figure 4. Depth profiles (in cm below the sediment-water interface) of dissolved inorganic nutrient $\left(\mathrm{NO}_{3}{ }^{-}, \mathrm{NH}_{4}{ }^{+}\right.$and $\left.\mathrm{PO}_{4}{ }^{3-}\right)$ concentrations in porewater for the three piezometers collected at each campaign. Reported values at a depth of $0 \mathrm{~cm}$ corresponds to the samples collected in surface waters $(\sim 10 \mathrm{~cm}$ above the sediment-water interface). Note that nutrient samples at Pz1 were not analyzed for the April 2017 survey.

Figure 5. Seasonal distribution of water depth, salinity and radon in the northern basin of La Palme lagoon. Points used to derive the interpolation for salinity and radon grids are shown. The main karstic spring is indicated with a black star. 
Figure 6. Dissolved inorganic nutrient $\left(\mathrm{NO}_{3}{ }^{-}, \mathrm{NH}_{4}{ }^{+}\right.$and $\left.\mathrm{PO}_{4}{ }^{3-}\right)$ concentrations in lagoon waters, the karstic spring, the sewage effluent and seawater endmembers, as a function of water salinity. The gray area represents the range of nutrient concentrations and salinities covering $66 \%$ of porewater samples (it extends to a salinity of 61 and to a $\mathrm{NH}_{4}{ }^{+}$concentration of $180 \mu \mathrm{mol} \mathrm{L}^{-1}$ ).

Figure 7. Evolution of water depths in the northern basin of La Palme lagoon in April and June 2017. Average changes in lagoon water level over time derived from linear regressions $\left(-0.0034\right.$ and $-0.0054 \mathrm{~m} \mathrm{~d}^{-1}$ for April and June 2017, respectively) were used to estimate $\frac{\partial V_{N}}{\partial t}$ for April 2017 and June 2017 campaigns. The short-term variations on water depth are likely produced by rapidly changing wind conditions and are expected to have a minor influence on the water mass balance.

Figure 8. Concentration of $\mathrm{NH}_{4}{ }^{+}$and $\mathrm{PO}_{4}{ }^{3-}$ plotted against radon concentrations in porewaters, arranged by piezometer and sampling campaign.

Figure 9. Fluxes of dissolved inorganic nutrients to the northern basin of La Palme lagoon driven by karstic groundwater discharge, lagoon water recirculation, diffusion, inputs from the sewage treatment plant and atmospheric deposition estimated for the different surveys. Boxes cover the range between minimum and maximum estimates (negative values not included), and black lines represent the average value. Inputs from atmospheric deposition on $\mathrm{NO}_{3}{ }^{-}$and $\mathrm{NH}_{4}{ }^{+}$panels refer to total DIN fluxes. 


\section{Figure 1}

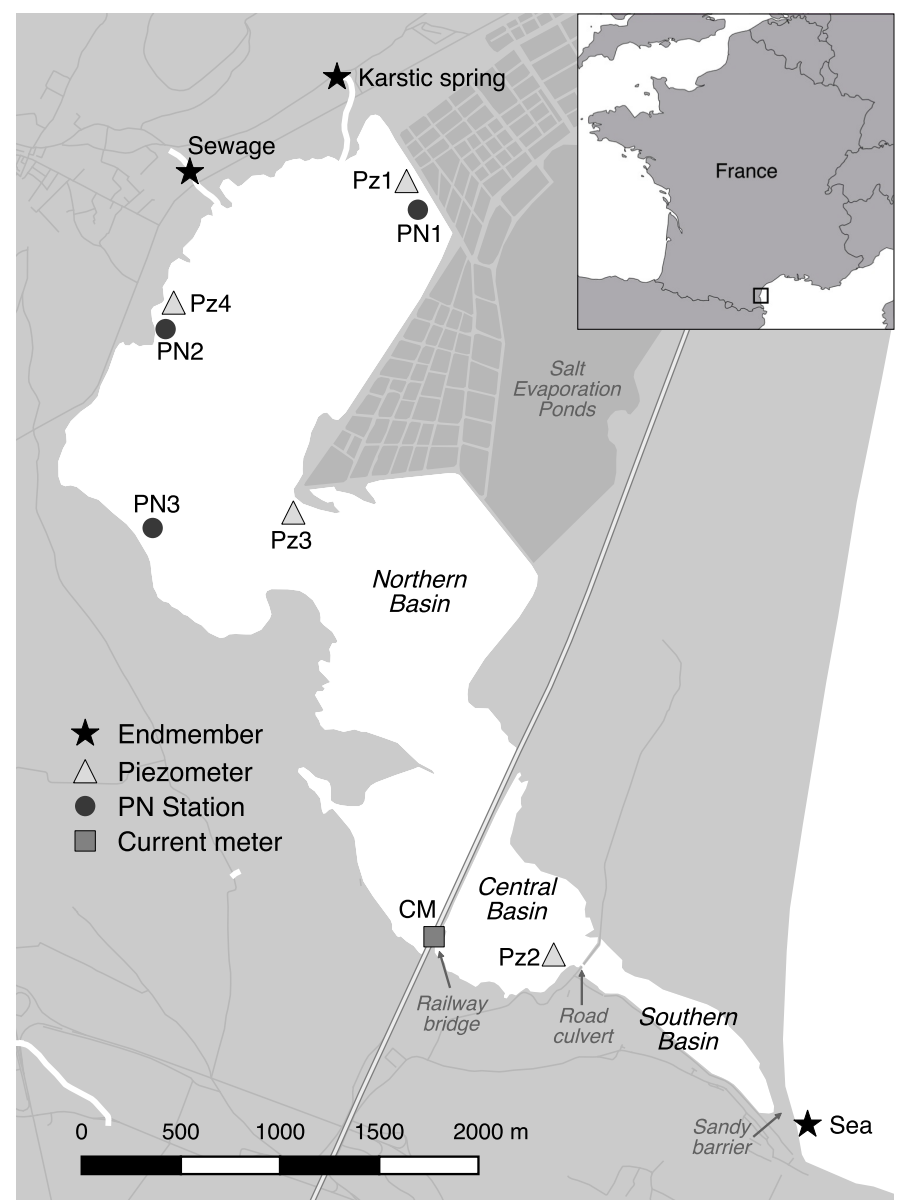


Figure 2
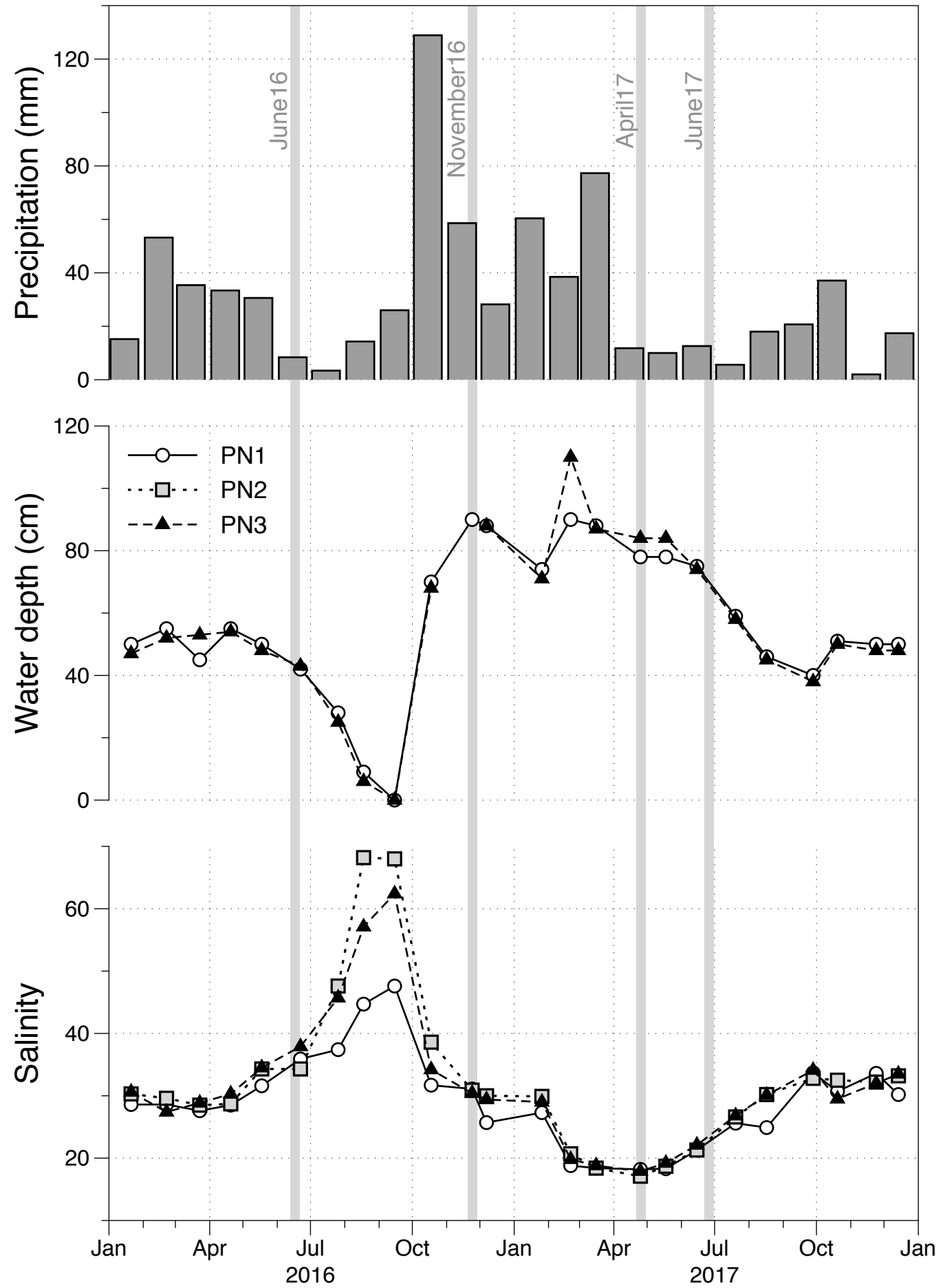


\section{Figure 3}

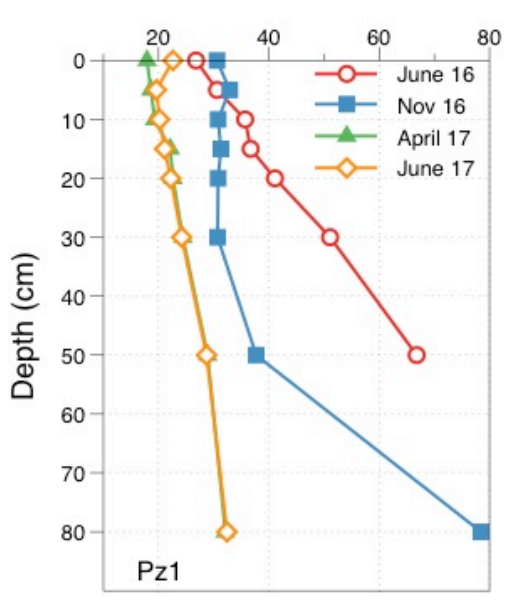

Salinity
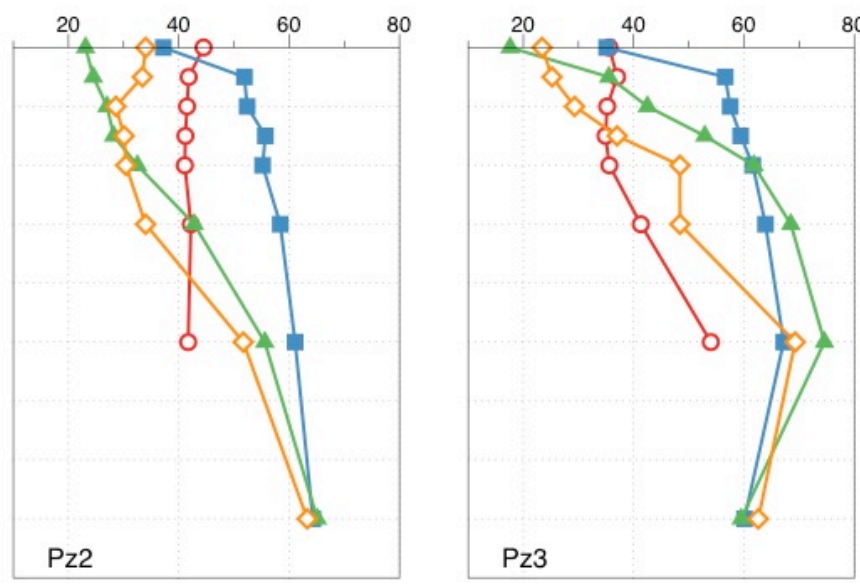

Radon (Bq m ${ }^{3}$ )
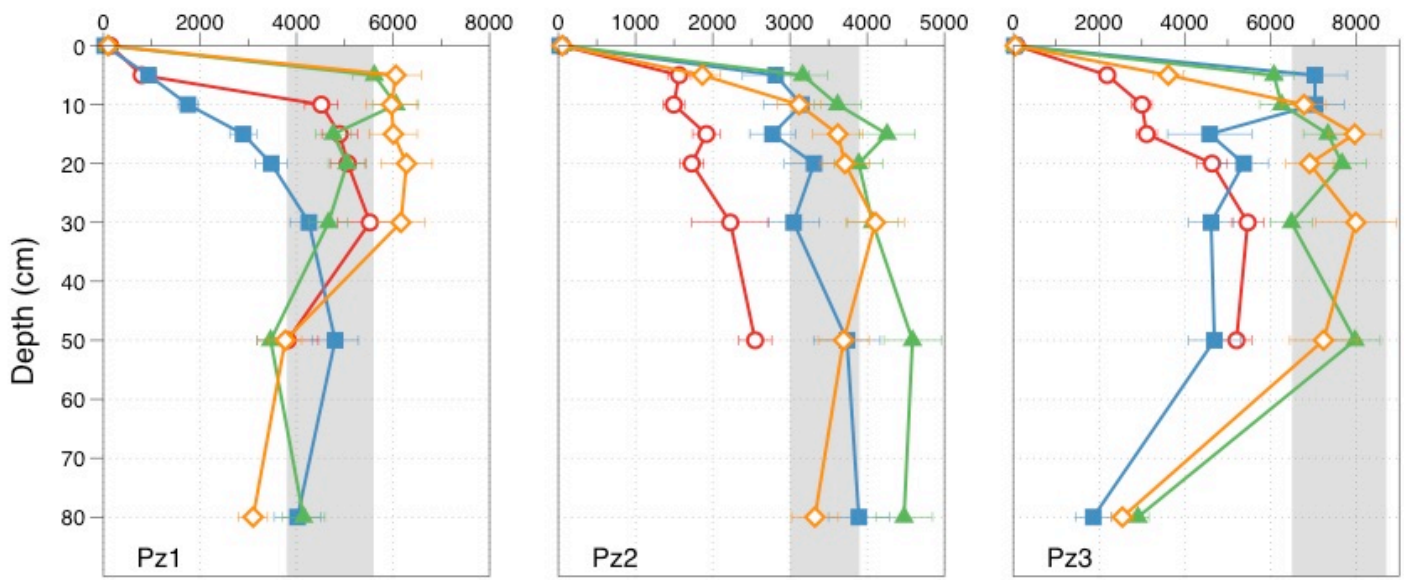


\section{Figure 4}
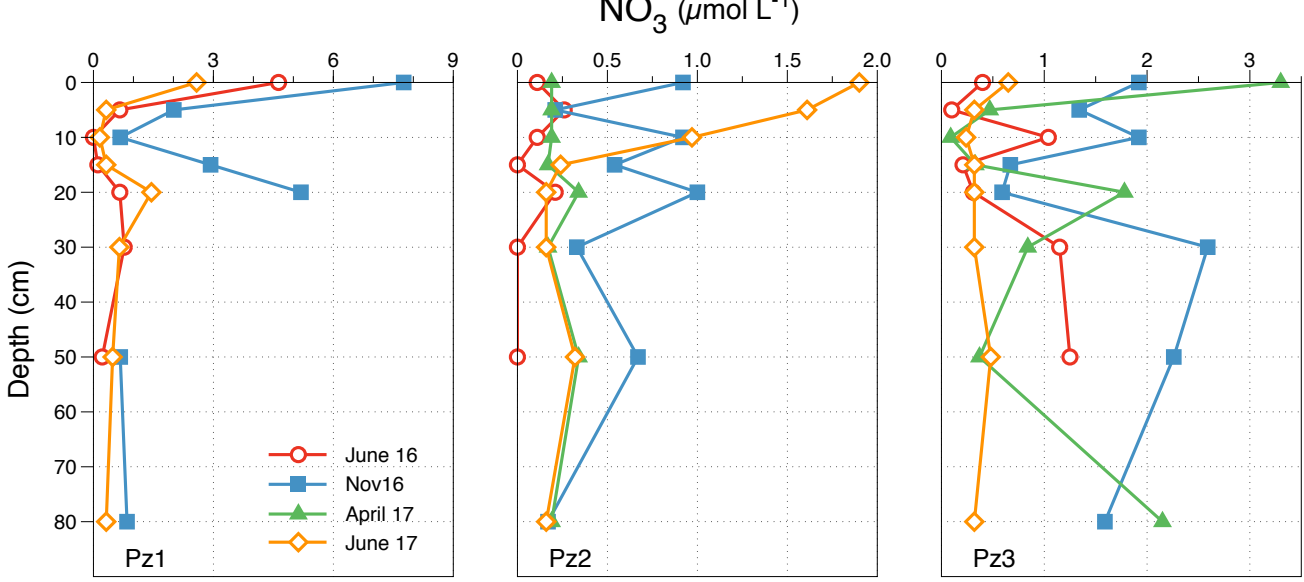

$\mathrm{NH}_{4}^{+}\left(\mu \mathrm{mol} \mathrm{L}^{-1}\right)$
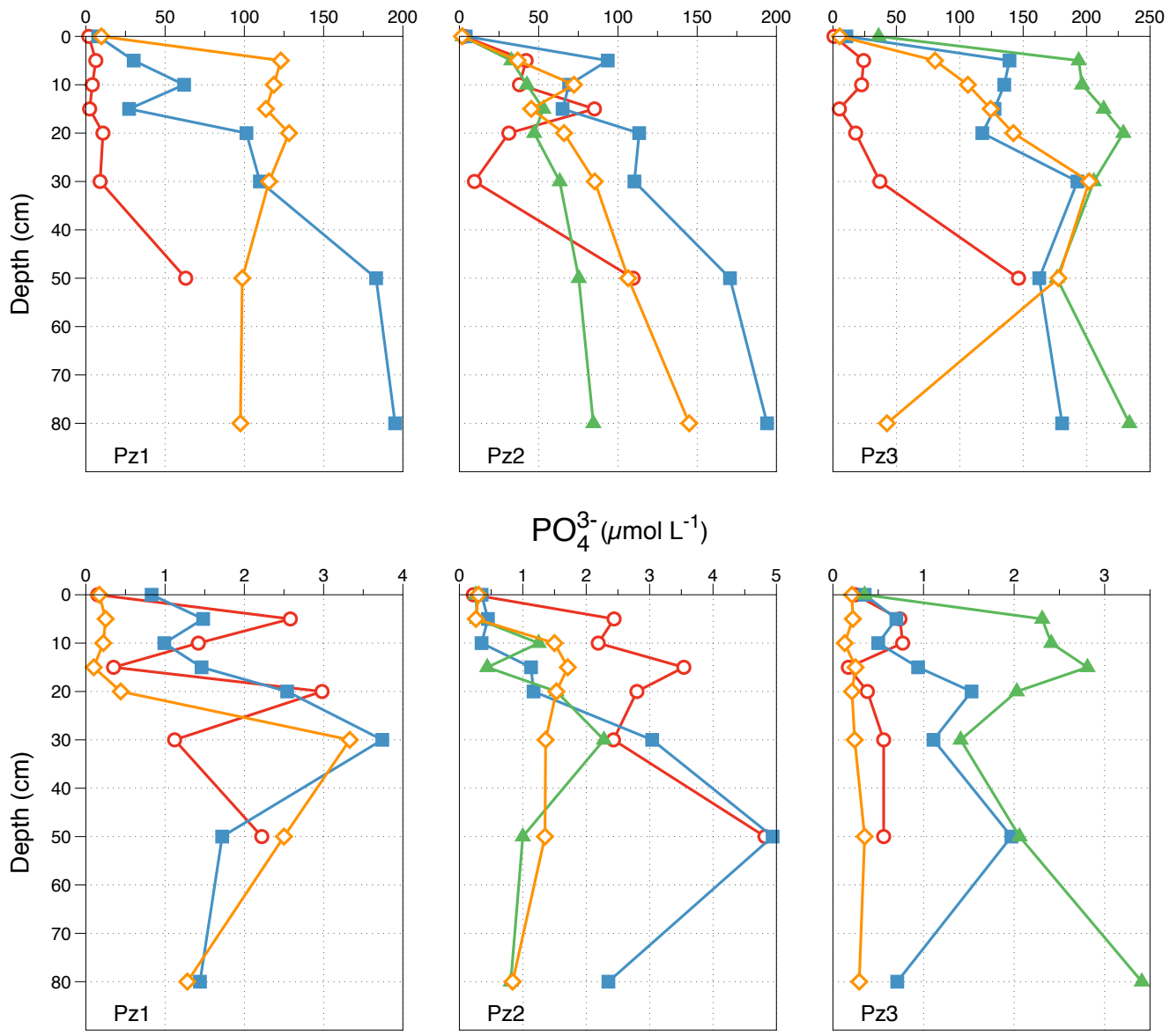
Figure 5
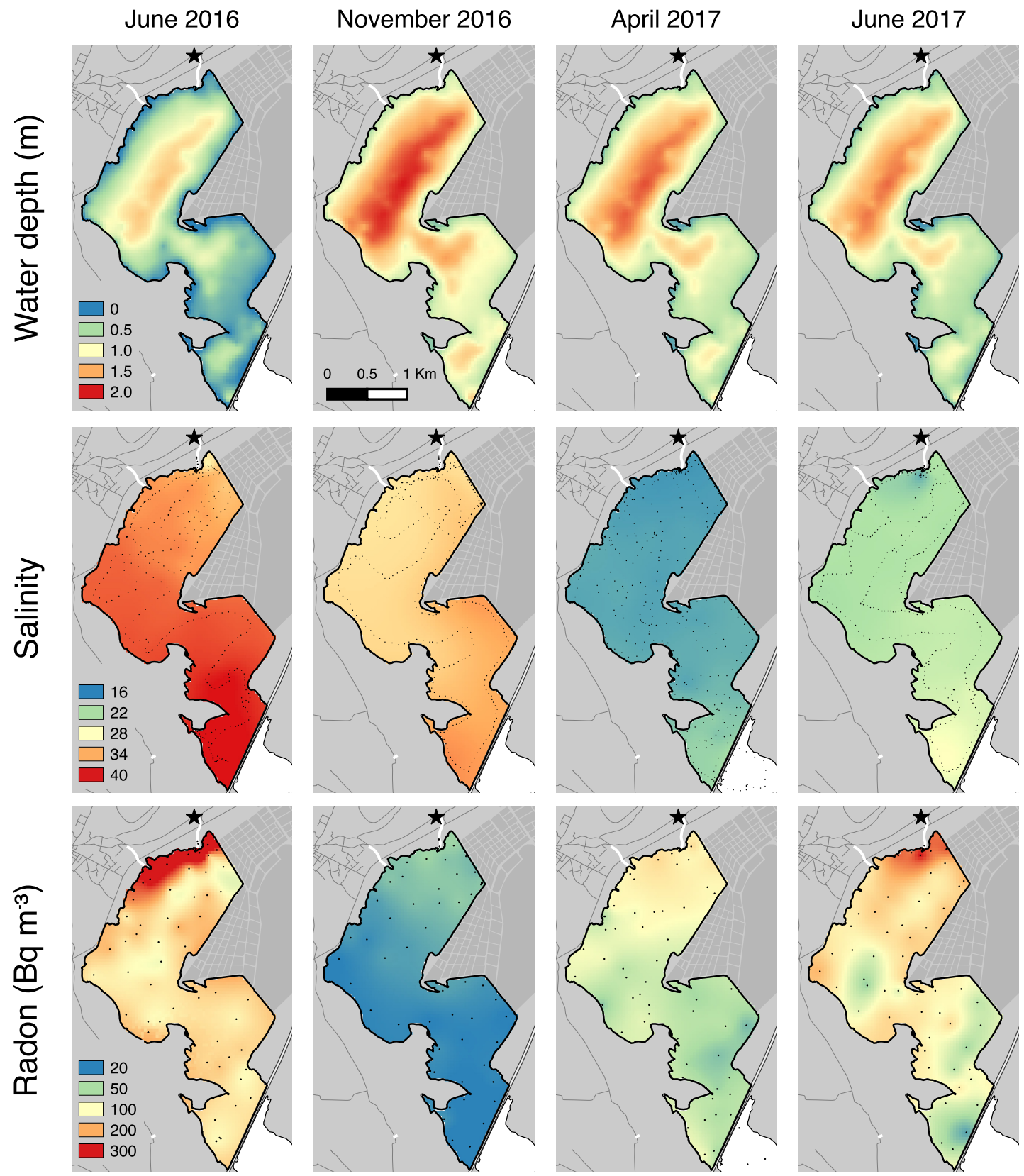
Figure 6
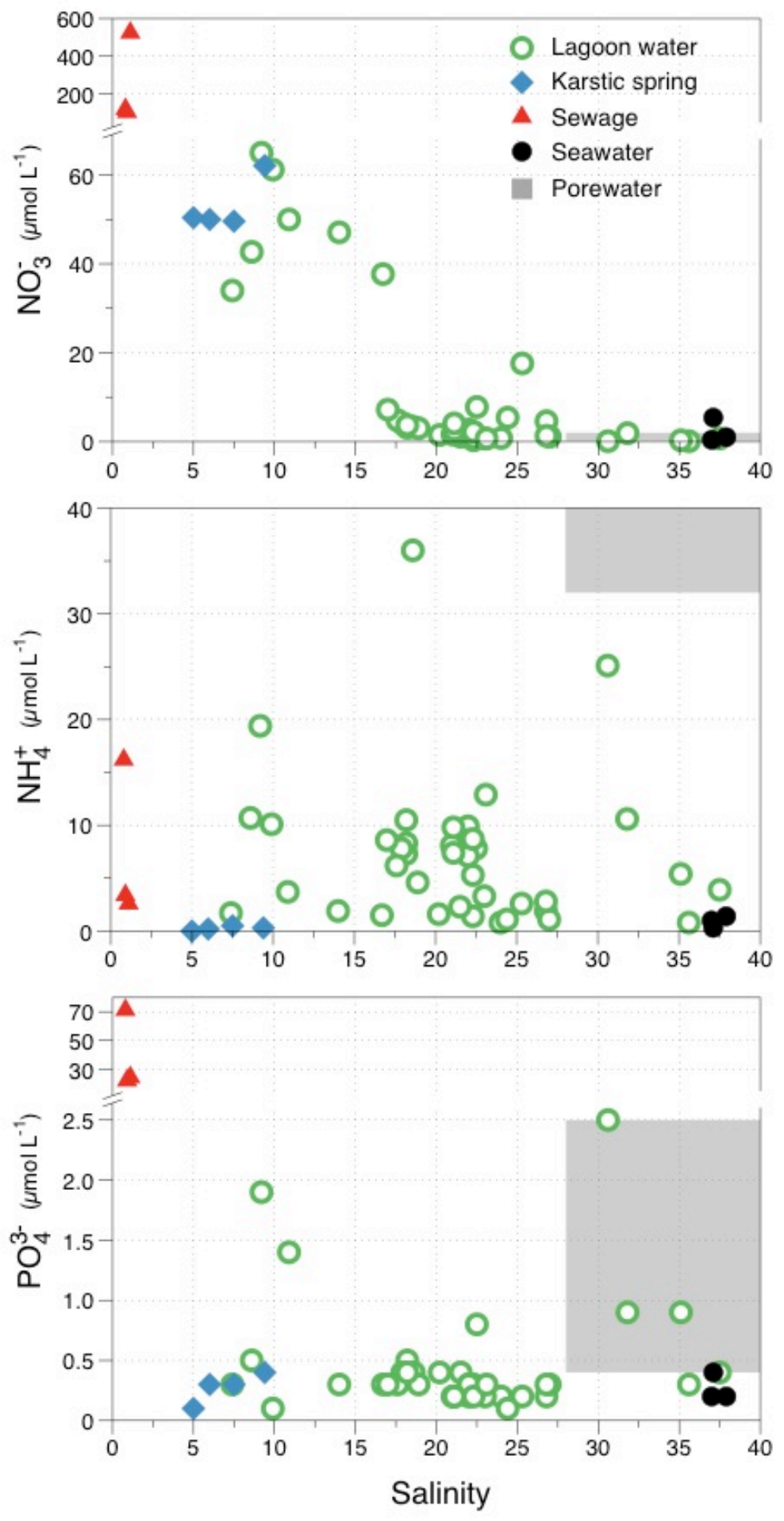


\section{Figure 7}
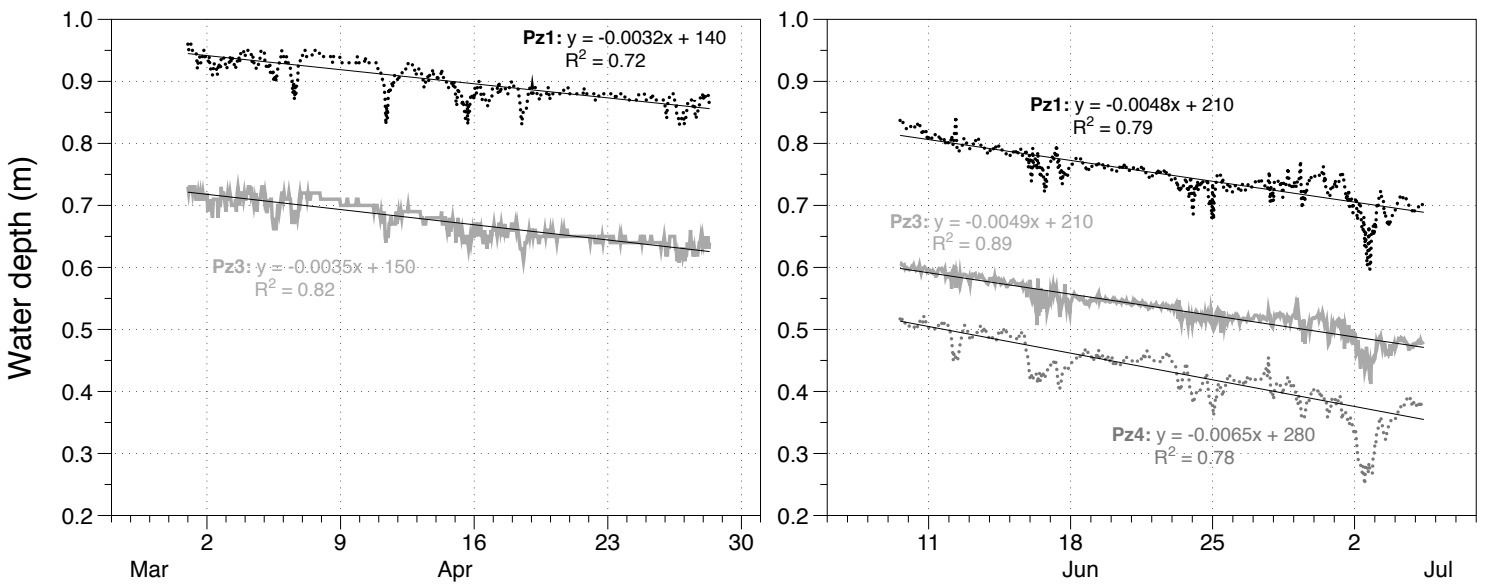
Figure 8
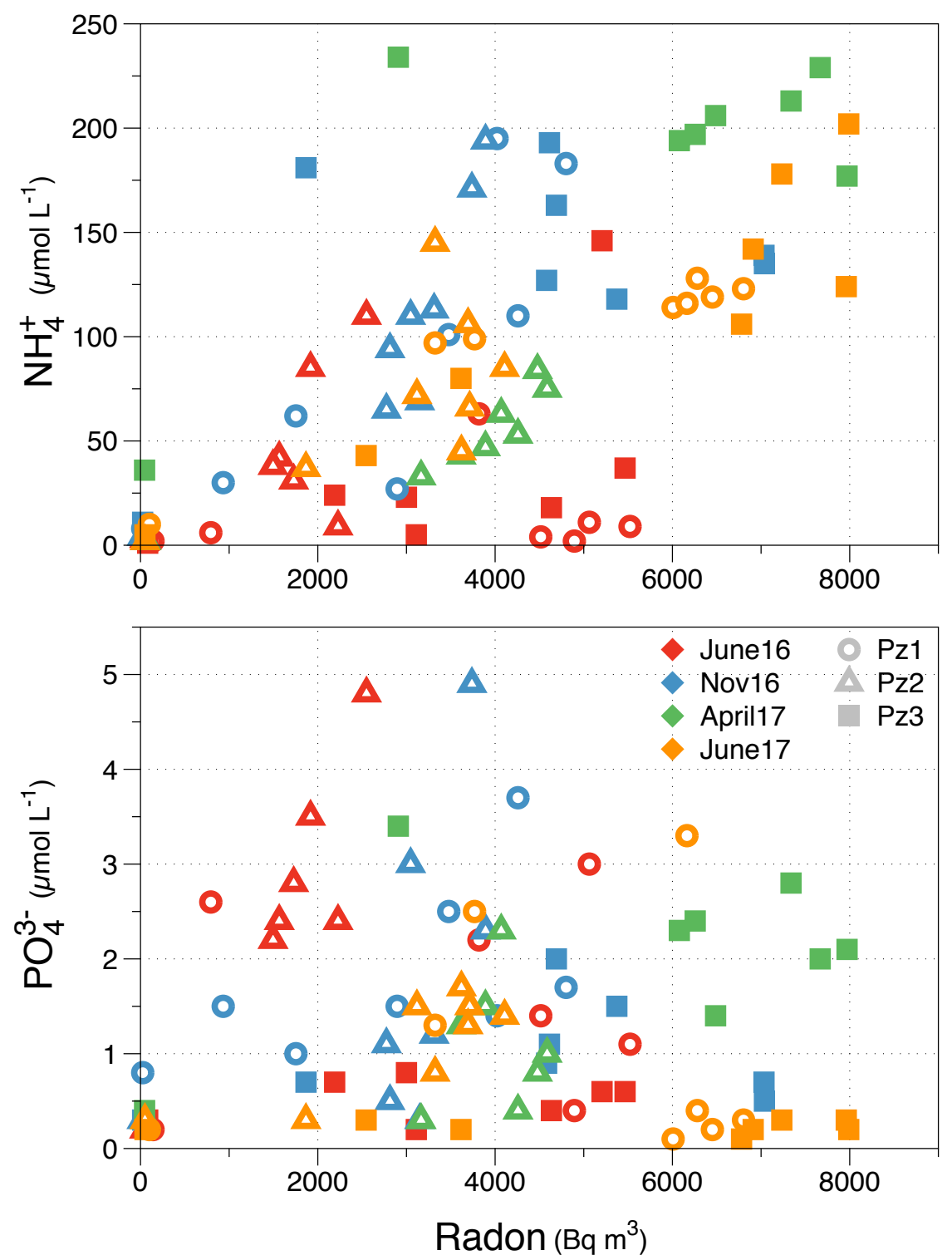
Figure 9
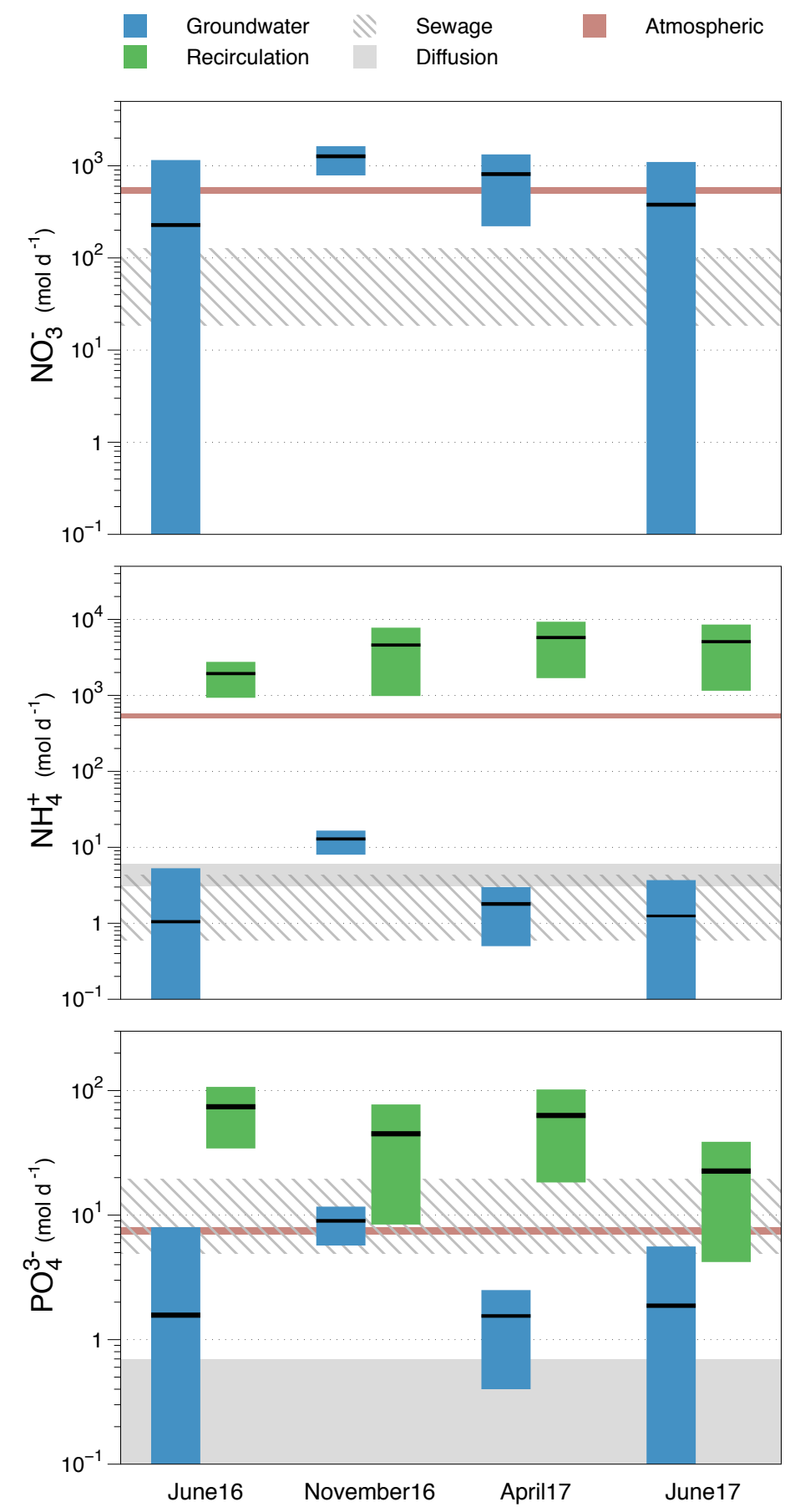


\section{TABLES}

Table 1. Definition of the terms and values used in the mass balances for water and radon based on Equations 1 and 3 . The terms estimated from the mass balance are highlighted in bold.

\section{Term Definition}

\section{WATER BALANCE}

$\begin{array}{ll}A_{N} & \text { Area Northern lagoon } \\ V_{N} & \text { Volume Northern lagoon } \\ d V_{N} / d t & \text { Change volume over time } \\ P & \text { Precipitation } \\ E & \text { Evaporation } \\ Q_{N C} & \text { Water flow from } \mathrm{N} \text { to } \mathrm{S}\end{array}$

\section{Summary water flows}

$P \cdot A_{N} \quad$ Total precipitation

$E \cdot A_{N} \quad$ Total evaporation

$Q_{N C} \quad$ Water flow from $N$ to $S$

$d V_{N} / d t \quad$ Change volume over time

\section{$Q_{g} \quad$ Karstic groundwater flow}

\section{RADON BALANCE}

$d C / d t \quad$ Change radon concentration over time

$C_{g} \quad$ Radon concentration groundwater 2600

$C_{\text {Ra226 }}$ Ra226 concentration

$C \quad$ Rn concentration in lagoon waters

$\lambda \quad$ Rn decay constant

$k \quad$ Gas transfer velocity

$F_{\text {diff }} \quad$ Radon diffusion flux from sediments

\section{Summary radon fluxes}

$d C V_{N} / d t \quad$ Change radon inventory over time

\section{June $16 \quad$ November 16}

Value Uncert.

$\begin{array}{cc}4.1 & 0.4 \\ 2.5 & 0.2 \\ -26 & -13 \\ 0.54 & 0.11 \\ 6.9 & 1.7 \\ 3.9 & 1.9 \\ & \\ 2.2 & 0.5 \\ 28 & 7 \\ 3.9 & 1.9 \\ -26 & -13 \\ 3 & 15 \\ & \\ 0 & \\ 2600 & 110 \\ 30 & 20 \\ 120 & 20 \\ 0.181 & \\ 0.3 & 0.1 \\ 12.5 & 1.6\end{array}$

0

Value Uncert.

$\begin{array}{cc}6.3 & 1.4 \\ 15 & 4 \\ 1.3 & 0.6 \\ 16 & 8 \\ 25 & 9\end{array}$

$\begin{array}{cc}0 & \\ 2290 & 90 \\ 30 & 20 \\ 23 & 7 \\ 0.181 & \\ 3.1 & 1.0 \\ 11.4 & 1.4\end{array}$

\section{April 16}

Value Uncert.

June 17 Unit

Value Uncert.

$\begin{array}{cc}4.4 & 0.4 \\ 5.3 & 0.5 \\ 16 & 8 \\ 1.41 & 0.28 \\ 3.3 & 0.8\end{array}$

$\begin{array}{cc}4.4 & 0.4 \\ 4.4 & 0.4 \\ -15 & -7 \\ 0.09 & 0.02 \\ 6.0 & 1.6 \\ 3.9 & 2.0\end{array}$

$$
\begin{gathered}
4.4 \\
4.0 \\
-24 \\
0.29 \\
6.5 \\
4.1
\end{gathered}
$$

0.4

$4.0 \quad 0.4$

$-24 \quad-12$

$0.29 \quad 0.06$

4.1

1.8

2.0

$\cdot 10^{6} \mathrm{~m}^{2}$

$.10^{6} \mathrm{~m}^{3}$

$\cdot 10^{3} \mathrm{~m}^{3} \mathrm{~d}^{-1}$

$\cdot 10^{-3} \mathrm{~m}^{3} \mathrm{~m}^{-2} \mathrm{~d}^{-1}$

$\cdot 10^{-3} \mathrm{~m}^{3} \mathrm{~m}^{-2} \mathrm{~d}^{-1}$

$\cdot 10^{3} \mathrm{~m}^{3} \mathrm{~d}^{-1}$

0.4

0.1

0.1
8
2.0

2.0

1.3

0.3

$\cdot 10^{3} \mathrm{~m}^{3} \mathrm{~d}^{-1}$

$\cdot 10^{3} \mathrm{~m}^{3} \mathrm{~d}^{-1}$

$\cdot 10^{3} \mathrm{~m}^{3} \mathrm{~d}^{-1}$

$\cdot 10^{3} \mathrm{~m}^{3} \mathrm{~d}^{-1}$

$\cdot 10^{3} \mathrm{~m}^{3} \mathrm{~d}^{-1}$

15

11

4.1

$-12$

15

$\mathrm{Bq} \mathrm{d}^{-1}$

$\begin{array}{cc}0 & \\ 2570 & 90\end{array}$

0

$\mathrm{Bq} \mathrm{m}^{-3}$

$\mathrm{Bq} \mathrm{m}^{-3}$

$\mathrm{Bq} \mathrm{m}^{-3}$

$\mathrm{d}^{-1}$

$\mathrm{m} \mathrm{d}^{-1}$

Bq $m^{-2} d^{-1}$

$\cdot 10^{6} \mathrm{~Bq} \mathrm{~d}^{-1}$ 


\begin{tabular}{|c|c|c|c|c|c|c|c|c|c|c|}
\hline$Q_{g} \cdot C_{g}$ & Radon flux from karstic groundwater & 9 & 39 & 57 & 20 & 39 & 28 & 18 & 36 & $\cdot 10^{6} \mathrm{~Bq} \mathrm{~d}^{-1}$ \\
\hline$\lambda \cdot V_{N} \cdot C_{R a 226}$ & Radon production from Ra decay & 13 & 9 & 29 & 19 & 24 & 16 & 22 & 15 & $\cdot 10^{6} \mathrm{~Bq} \mathrm{~d}^{-1}$ \\
\hline$k \cdot A_{N} \cdot C$ & Radon gas loss & 130 & 50 & 310 & 140 & 320 & 170 & 250 & 160 & $\cdot 10^{6} \mathrm{~Bq} \mathrm{~d}^{-1}$ \\
\hline$\lambda \cdot V_{N} \cdot C$ & Radon decay & 85 & 20 & 18 & 6 & 52 & 14 & 75 & 21 & $\cdot 10^{6} \mathrm{~Bq} \mathrm{~d}^{-1}$ \\
\hline$F_{\text {diff }} \cdot A_{N}$ & Total radon diffusion from sediments & 51 & 8 & 51 & 8 & 55 & 9 & 60 & 9 & $\cdot 10^{6} \mathrm{~Bq} \mathrm{~d}^{-1}$ \\
\hline $\boldsymbol{F}_{\text {recirc }} \cdot \boldsymbol{A}_{\boldsymbol{N}}$ & Total radon inputs from recirculation & 140 & 70 & 190 & 140 & 250 & 170 & 220 & 170 & $\cdot 10^{6} \mathrm{~Bq} \mathrm{~d}^{-1}$ \\
\hline $\boldsymbol{F}_{\text {recirc }}$ & Rn inputs from recirculation & 35 & 16 & 43 & 33 & 57 & 39 & 51 & 38 & $\mathrm{~Bq} \mathrm{~m}^{-2} \mathrm{~d}^{-1}$ \\
\hline
\end{tabular}


Table 2. Summary of the approaches used to estimate values and uncertainties of all the terms used on Equations 1, 3, 4 and 5.

\section{Term Definition}

\section{WATER BALANCE}

$A_{N} \quad$ Area Northern lagoon

$A_{C+S} \quad$ Area Central and Southern lagoon

$V_{N} \quad$ Volume Northern lagoon

$d V_{N} / d t$ Change volume over time

P Precipitation

E Evaporation

$Q_{N C} \quad$ Water flow from $\mathrm{N}$ to $\mathrm{S}$

$Q_{g} \quad$ Karstic groundwater flow

\section{RADON BALANCE}

$d C / d t \quad$ Change radon concentration over time

$C_{g} \quad$ Radon concentration groundwater

$C_{\text {Ra226 Ra226 concentration }}$

$C$ Rn concentration in lagoon waters

$\lambda \quad$ Rn decay constant

$\theta \quad$ Porosity

$D_{s} \quad$ Radon diffusion coefficient

$c_{e q} \quad$ Radon in equilibrium with sediments

$A_{\text {sed-pz }} \quad$ Sediment area representative of each $\mathrm{Pz}$

$F_{\text {diff }} \quad$ Radon diffusion flux from sediments

$u \quad$ Wind speed

k Gas transfer velocity

$F_{\text {recirc }} \quad \mathrm{Rn}$ inputs from recirculation

\section{Estimation of value}

Digitalization from GoogleEarth images + bathymetry grids Digitalization from GoogleEarth images + bathymetry grids $A_{N} *$ average depth from bathymetry grids

Water level change from PN monthly measurements (June16, Novembre16) and water level loggers (April17, June17)

Average precipitation 10 days before surveys (MétéoFrance)

Average evaporation 10 days before surveys, derived from Penman equation and weather data (MétéoFrance)

$(P-E) * A_{C+S}$

Water mass balance (Eq. 1)

Assumed to be 0

Radon measured in karstic spring

Average ${ }^{226}$ Ra concentration in surface waters $(n=10)$

Weighted-average radon (from radon distribution grid)

Known

Calculated in Tamborski et al (submitted)

After Peng et al. (1974) and Ullman and Aller (1982)

Equilibration experiments (average of 3 samples at each piezometer) Estimated from sediment distribution maps (IFREMER, 2003)

Depth-independent approach (Eq.4)

Average hourly wind speed from 48 hours before the survey

After Maclntyre equation (Eq. 5)

Radon mass balance (Eq. 3 )

\section{Estimation of uncertainty}

Relative unc. of $10 \%$ assumed Relative unc. of $10 \%$ assumed Relative unc. of $10 \%$ assumed

Relative unc. of $50 \%$ assumed

Relative unc. of $20 \%$ assumed

\section{Standard deviation}

Propagation uncertainties

Propagation uncertainties

Analytical uncertainty

Range covering all values

Range covering distribution grids of min and max radon

Standard deviation

Absolute unc. of $5 \%$ assumed

Propagation uncertainties

Range covering $50 \%$ of hourly wind speeds (Q1-Q3)

Propagation uncertainties

Propagation uncertainties 
Table 3. Water flows, endmember nutrient concentrations and nutrient fluxes from karstic groundwater and lagoon water recirculation to the northern basin of La Palme lagoon for the different surveys. The recirculation nutrient endmember refers to weighted-average excess nutrient concentrations (samples collected at $5 \mathrm{~cm}$ below the sediment-water interface at each piezometer) for each survey.

\begin{tabular}{|c|c|c|c|c|c|c|c|c|c|c|c|}
\hline & \multicolumn{2}{|c|}{ Water flow } & \multicolumn{3}{|c|}{ Nutrient endmember } & \multicolumn{6}{|c|}{ Nutrient flux } \\
\hline & & & $\mathrm{NO}_{3}^{-}$ & $\mathrm{NH}_{4}^{+}$ & $\mathrm{PO}_{4}^{3-}$ & $\mathrm{NO}_{3}$ & & $\mathbf{N}$ & & $\mathrm{PO}_{4}{ }^{3}$ & \\
\hline & $\cdot 10^{3} \mathrm{~m}^{3} \mathrm{~d}^{-1}$ & $\Delta$ & $\mu \mathrm{mol} \mathrm{L} \mathrm{L}^{-1}$ & $\mu \mathrm{mol} \mathrm{L} \mathrm{L}^{-1}$ & $\mu \mathrm{mol} \mathrm{L}^{-1}$ & $\mathrm{~mol} \mathrm{~d}^{-1}$ & $\Delta$ & $\mathrm{mol} \mathrm{d}^{-1}$ & $\Delta$ & $\mathrm{mol} \mathrm{d}^{-1}$ & $\Delta$ \\
\hline \multicolumn{12}{|l|}{ June 2016} \\
\hline Karstic Groundwater & 3 & 15 & 62 & 0.28 & 0.43 & 220 & 900 & 1.0 & 4.3 & 1.5 & 6.5 \\
\hline Recirculation & 89 & 44 & -2.7 & 21 & 0.79 & -240 & 130 & 1900 & 900 & 71 & 36 \\
\hline \multicolumn{12}{|l|}{ November 2016} \\
\hline Karstic Groundwater & 25 & 9 & 48 & 0.49 & 0.35 & 1200 & 400 & 12 & 4 & 8.7 & 3.0 \\
\hline Recirculation & 42 & 33 & -8.1 & 103 & 1.0 & -340 & 280 & 4400 & 3400 & 43 & 34 \\
\hline \multicolumn{12}{|l|}{ April 2017} \\
\hline Karstic Groundwater & 15 & 10 & 51 & 0.12 & 0.10 & 780 & 540 & 1.7 & 1.2 & 1.5 & 1.0 \\
\hline Recirculation & 48 & 32 & -1.8 & 115 & 1.3 & -87 & 59 & 5500 & 3800 & 60 & 41 \\
\hline \multicolumn{12}{|l|}{ June 2017} \\
\hline Karstic Groundwater & 7 & 14 & 50 & 0.17 & 0.25 & 360 & 730 & 1.2 & 2.4 & 1.8 & 3.7 \\
\hline Recirculation & 55 & 42 & -0.6 & 87 & 0.39 & -35 & 27 & 4900 & 3700 & 22 & 17 \\
\hline
\end{tabular}

